\title{
Temporal and spatial variation of nitrogen transformations in nitrogen-saturated soils of a central Appalachian hardwood forest
}

\author{
Frank S. Gilliam, Bradley M. Yurish, and Mary Beth Adams
}

\begin{abstract}
We studied temporal and spatial patterns of soil nitrogen (N) dynamics from 1993 to 1995 in three watersheds of Fernow Experimental Forest, W.V.: WS7 (24-year-old, untreated); WS4 (mature, untreated); and WS3 (24year-old, treated with $\left(\mathrm{NH}_{4}\right)_{2} \mathrm{SO}_{4}$ since 1989 at the rate of $35 \mathrm{~kg} \mathrm{~N} \cdot \mathrm{ha}^{-1}$.year $\left.{ }^{-1}\right)$. Net nitrification was 141, 114, and $115 \mathrm{~kg} \mathrm{~N} \cdot \mathrm{ha}^{-1} \cdot \mathrm{year}^{-1}$, for WS3, WS4, and WS7, respectively, essentially $100 \%$ of net $\mathrm{N}$ mineralization for all watersheds. Temporal (seasonal) patterns of nitrification were significantly related to soil moisture and ambient temperature in untreated watersheds only. Spatial patterns of soil water $\mathrm{NO}_{3}{ }^{-}$of WS4 suggest that microenvironmental variability limits rates of $\mathrm{N}$ processing in some areas of this $\mathrm{N}$-saturated watershed, in part by ericaceous species in the herbaceous layer. Spatial patterns of soil water $\mathrm{NO}_{3}{ }^{-}$in treated WS3 suggest that later stages of $\mathrm{N}$ saturation may result in higher concentrations with less spatial variability. Spatial variability in soil N variables was lower in treated WS3 versus untreated watersheds. Nitrogen additions have altered the response of N-processing microbes to environmental factors, becoming less sensitive to seasonal changes in soil moisture and temperature. Biotic processes responsible for regulating $\mathrm{N}$ dynamics may be compromised in $\mathrm{N}$-saturated forest ecosystems.
\end{abstract}

Résumé : Nous avons étudié les patrons temporels et spatiaux de la dynamique de l'azote (N) du sol, de 1993 à 1995 , dans trois bassins versants de la forêt expérimentale de Fernow : WS7 (âgé de 24 ans et non traité); WS4 (mature et non traité); WS3 (âgé de 24 ans et traité avec $\left(\mathrm{NH}_{4}\right)_{2} \mathrm{SO}_{4}$ depuis 1989 au taux de $35 \mathrm{~kg} \mathrm{~N} \cdot \mathrm{ha}^{-1} \cdot \mathrm{an}^{-1}$ ). La nitrification nette était respectivement de 141,114 et $115 \mathrm{~kg} \mathrm{~N} \cdot \mathrm{ha}^{-1} \cdot \mathrm{an}^{-1}$ pour WS3, WS4 et WS7, soit essentiellement $100 \%$ de la minéralisation nette pour tous les bassins versants. Les patrons temporels (saisonniers) de nitrification étaient significativement reliés à l'humidité du sol et à la température ambiante seulement dans les bassins versants non traités. Les patrons spatiaux de $\mathrm{NO}_{3}{ }^{-}$de la solution de sol du WS4 indiquent que la variabilité micro-environnementale limite le taux de recyclage de $\mathrm{N}$ dans certaines aires de ce bassin versant saturé en $\mathrm{N}$, en partie à cause des espèces d'éricacées présentes dans la strate herbacée. Les patrons spatiaux de $\mathrm{NO}_{3}{ }^{-}$de la solution du sol dans le WS3 traité indiquent que des stades plus avancés de saturation de $\mathrm{N}$ peuvent se traduire par de plus fortes concentrations avec moins de variabilité spatiale. La variabilité spatiale des variables de $\mathrm{N}$ du sol était plus faible dans le WS3 comparativement aux bassins versants non traités. Les ajouts de $\mathrm{N}$ ont altéré la réponse des microorganismes associés au cycle de $\mathrm{N}$ vis-à-vis les facteurs environnementaux en les rendant moins sensibles aux changements saisonniers d'humidité et de température du sol. Les processus biotiques responsables de la régulation de la dynamique de $\mathrm{N}$ peuvent être compromis dans les écosystèmes forestiers saturés en $\mathrm{N}$.

[Traduit par la Rédaction]

\section{Introduction}

Although the 1990 Clean Air Act Amendments included stricter requirements to reduce emissions of $\mathrm{SO}_{2}$ and $\mathrm{NO}_{x}$, such restrictions have been more effective in controlling sulfur than nitrogen $(\mathrm{N})$ in the atmosphere (Holland et al. 1999). Lynch et al. (2000) reported 10-25\% reductions in $\mathrm{SO}_{4}{ }^{2-}$ concentrations in wet precipitation from 1995 to 1997

Received August 22, 2000. Accepted May 17, 2001.

Published on the NRC Research Press Web site at

http://cjfr.nrc.ca on September 28, 2001.

F.S. Gilliam ${ }^{1}$ and B.M. Yurish. Department of Biological Sciences, Marshall University, Huntington, WV 25755-2510, U.S.A.

M.B. Adams. USDA Forest Service, Timber and Watershed Laboratory, Parsons, WV 26287, U.S.A.

${ }^{1}$ Corresponding author (e-mail: gilliam@ marshall.edu). compared with the previous 12-year period for 54 sites throughout the eastern United States, with negligible change over the same period for $\mathrm{NO}_{3}^{-}$. These high rates of atmospheric $\mathrm{N}$ deposition have contributed to $\mathrm{N}$ saturation ( $\mathrm{N}$ supply > $\mathrm{N}$ demand) in some forested areas of the United States.

Although much of the $\mathrm{N}$-saturation research in the United States has been in conifer and hardwood forests of the Northeast (Kahl et al. 1993; McNulty and Aber 1993; Rustad et al. 1993; Norton et al. 1994; Currie 1999; Magill et al. 2000), several ecosystems across the United States have been found to be $\mathrm{N}$ saturated, including Colorado Rocky Mountain tundra (Baron et al. 1994; Williams et al. 1996), chaparral and high-elevation sites in southern California (Riggan et al. 1985; Fenn et al. 1996; Fenn and Poth 1999), hardwood forests of the Catskill Mountains (Lovett et al. 2000), and spruce-fir stands of the Northeast (McNulty et al. 1996) and Great Smoky Mountains (Johnson et al. 1991). 
Central Appalachian forests have the potential for $\mathrm{N}$ saturation, given the levels of atmospheric inputs of $\mathrm{N}$ (Gilliam and Adams 1996).

In $\mathrm{N}$-limited forests, $\mathrm{NH}_{4}{ }^{+}$released during $\mathrm{N}$ mineralization is either taken up by plants or immobilized by microbial heterotrophs. Theoretically, little $\mathrm{NH}_{4}{ }^{+}$is available to nitrifying bacteria, resulting in low nitrification rates, although gross nitrification can occur under these conditions (Davidson et al. 1992). Uptake or immobilization of available $\mathrm{N}$ in $\mathrm{N}$-limited forests is generally rapid, so available $\mathrm{N}$ pools are usually quite small even though turnover rates of $\mathrm{N}$ may be high (Vitousek and Matson 1985). Thus, symptoms of $\mathrm{N}$ saturation (Aber et al. 1989, 1998) include increased nitrification rates and levels of extractable $\mathrm{N}$ in mineral soil, especially $\mathrm{NO}_{3}^{-}$.

Seasonal patterns of soil $\mathrm{NO}_{3}{ }^{-}$are particularly important because of its mobile nature and ability to leach essential base cations (Adams et al. 1993; Gilliam et al. 1996; Currie et al. 1999). Soil cation depletion, reported for several forest sites in the eastern United States (Lawrence et al. 1995; Likens et al. 1996), represents a challenge to sustainable management of $\mathrm{N}$-saturated forests (Fenn et al. 1998; Gilliam and Adams 1999; Adams 1999; McLaughlin and Wimmer 1999). Declines in productivity have been documented at several N-saturated sites (Eagar and Adams 1992; Aber et al. 1995; McNulty et al. 1996; Magill et al. 1997).

Although watershed-scale patterns of soil $\mathrm{N}$ have received little attention in these $\mathrm{N}$-saturated ecosystems, soil $\mathrm{N}$ dynamics are controlled by processes that often are spatially heterogeneous (Schimel et al. 1985; Schlesinger et al. 1996), an important factor in determining ecosystem response to disturbance (Walley et al. 1996). For example, whereas spatially discrete areas of high $\mathrm{N}$ mineralization rates in soils may serve as the source of $\mathrm{N}$ loss following disturbance, similar areas of low net $\mathrm{N}$ mineralization from high $\mathrm{N}$ immobilization may serve as an $\mathrm{N}$ sink, thereby mitigating the ecosystem-level loss of N. Some studies have found spatial variability of $\mathrm{N}$ processing in forest soils to be related to gap formation and leaf litter chemistry of contrasting tree species (Mladenoff 1987; Ferrari 1999), whereas other studies have found hydrologic regime and soil moisture to determine spatial patterns in soil N dynamics (Ohrui and Mitchell 1998; Devito et al. 1999; Ohrui et al. 1999; Morris and Boerner 1998, 1999).

In 1988, the USDA Forest Service initiated a project at the Fernow Experimental Forest (FEF), Parsons, W.V., to examine the effects of watershed-scale additions of $\left(\mathrm{NH}_{4}\right)_{2} \mathrm{SO}_{4}$ on temporal changes in stream chemistry (Adams et al. 1993, 1997) and on nutrient cycling within soils and herbaceous layer plants (Gilliam et al. 1994). Evidence from these and other studies indicate that even some untreated watersheds of FEF have become N saturated (Stoddard 1994).

In this paper we examine the effects of experimentally elevated $\mathrm{N}$ inputs to an $\mathrm{N}$-saturated forest ecosystem by analyzing temporal and spatial patterns of net $\mathrm{N}$ mineralization and nitrification and available $\mathrm{N}$ pools and test for environmental factors that influence these patterns. We addressed the following questions. What are rates of net nitrification in $\mathrm{N}$-saturated soils relative to net $\mathrm{N}$ mineralization? How sensitive are inorganic $\mathrm{N}$ transformations and pools to added $\mathrm{N}$ ?
What factors influence temporal patterns of net nitrification? What is the effect of $\mathrm{N}$ additions on spatial variability of soil $\mathrm{N}$ dynamics within these watersheds? What factors influence spatial patterns of soil $\mathrm{N}$ dynamics within FEF watersheds?

\section{Methods}

\section{Study site}

The Fernow Experimental Forest occupies approximately 1900 ha of the Allegheny Mountain section of the unglaciated Allegheny Plateau near Parsons, W.V. (39 $\left.03^{\prime} \mathrm{N}, 79^{\circ} 49^{\prime} \mathrm{W}\right)$. Precipitation at FEF averages approximately $1430 \mathrm{~mm} / \mathrm{year}$, being higher during the growing season and increasing with elevation. Concentrations of acidic species in wetfall $\left(\mathrm{H}^{+}, \mathrm{SO}_{4}{ }^{2-}\right.$, and $\left.\mathrm{NO}_{3}{ }^{-}\right)$are among the highest in North America (Gilliam and Adams 1996). Watershed soils are coarse-textured Inceptisols (loamy-skeletal, mixed mesic Typic Dystrochrept) of the Berks and Calvin series, sandy loams derived from sandstone (Gilliam et al. 1994).

Dominant tree species on FEF watersheds vary with stand age. Early successional species, such as black birch (Betula lenta L.), black cherry (Prunus serotina Ehrh.), and yellow-poplar (Liriodendron tulipifera L.) are dominant in young stands, whereas latesuccessional species, such as sugar maple (Acer saccharum Marshall) and northern red oak (Quercus rubra L.), are dominant in mature stands (Gilliam et al. 1995). Dominant herbaceous layer species vary less with stand age and include stinging nettle (Laportea canadensis (L.) Wedd.), violets (Viola spp.), and several ferns (Gilliam et al. 1994). Note that nomenclature follows Gleason and Cronquist (1991).

Three watersheds served as study sites: WS4 (>80-year-old mixed-age stand), WS7 ( 24-year-old even-age stand), and WS3 ( 24-year-old even-age stand); WS3 served as the "treatment" watershed, whereas WS4 and WS7 were the controls. WS3 has received three aerial applications of $\left(\mathrm{NH}_{4}\right)_{2} \mathrm{SO}_{4}$ per year, beginning in 1989. March (or sometimes April) and November applications represent approximately $7.1 \mathrm{~kg} \mathrm{~N} \cdot \mathrm{ha}^{-1}$; July applications are approximately $21.2 \mathrm{~kg} \mathrm{~N} \cdot \mathrm{ha}^{-1}$. These rates were chosen as approximately twice the ambient rates of $\mathrm{N}$ inputs to the watersheds via atmospheric deposition. The total amount of $\mathrm{N}$ deposited on WS3 (application plus atmospheric deposition) is approximately $54 \mathrm{~kg}$ $\mathrm{N} \cdot \mathrm{ha}^{-1} \cdot \mathrm{year}^{-1}$, or about three times ambient inputs (Adams et al. 1993).

\section{Field sampling}

On each of WS3 and WS4, 15 circular plots (0.04-ha) were established adjacent to zero-tension lysimeters (see Water chemistry below); 15 plots were also established on WS7, although not adjacent to lysimeters, which had not been previously installed on WS7 (Fig. 1). Seven of these plots were selected in each watershed to represent its full range of elevation and slope aspect as a subset of 15 plots established for earlier work on soil-plant interactions (see Gilliam et al. 1994) (Fig. 1).

Mineral soil was collected by hand trowel at five points within each of the seven plots per watershed to a depth of $5 \mathrm{~cm}$. These five samples were composited, thoroughly mixed, and then placed in two polyethylene bags; one was brought back to the laboratory for immediate extraction and analysis (see below), and the other was incubated in situ by burying it $5 \mathrm{~cm}$ beneath the mineral soil surface for $\sim 30$ days during the growing season from 1993 to 1995. In 1993, incubations were conducted from June to September; the soil collected in October was incubated until May 1994. In 1994, sampling was carried out from May to September; the October sample was incubated until April 1995. Sampling for 1995 was done from April until October. 
Fig. 1. Three study watersheds within the Fernow Experimental Forest, West Virginia. Points within each watershed indicate location of sample plots. Locations on WS3 (treated) and WS4 (untreated) are for lysimeter or vegetation plots of earlier and ongoing studies, with plots also used for in situ incubations indicated by asterisks. Locations for WS7 (untreated) are indicated for in situ incubation plots only.

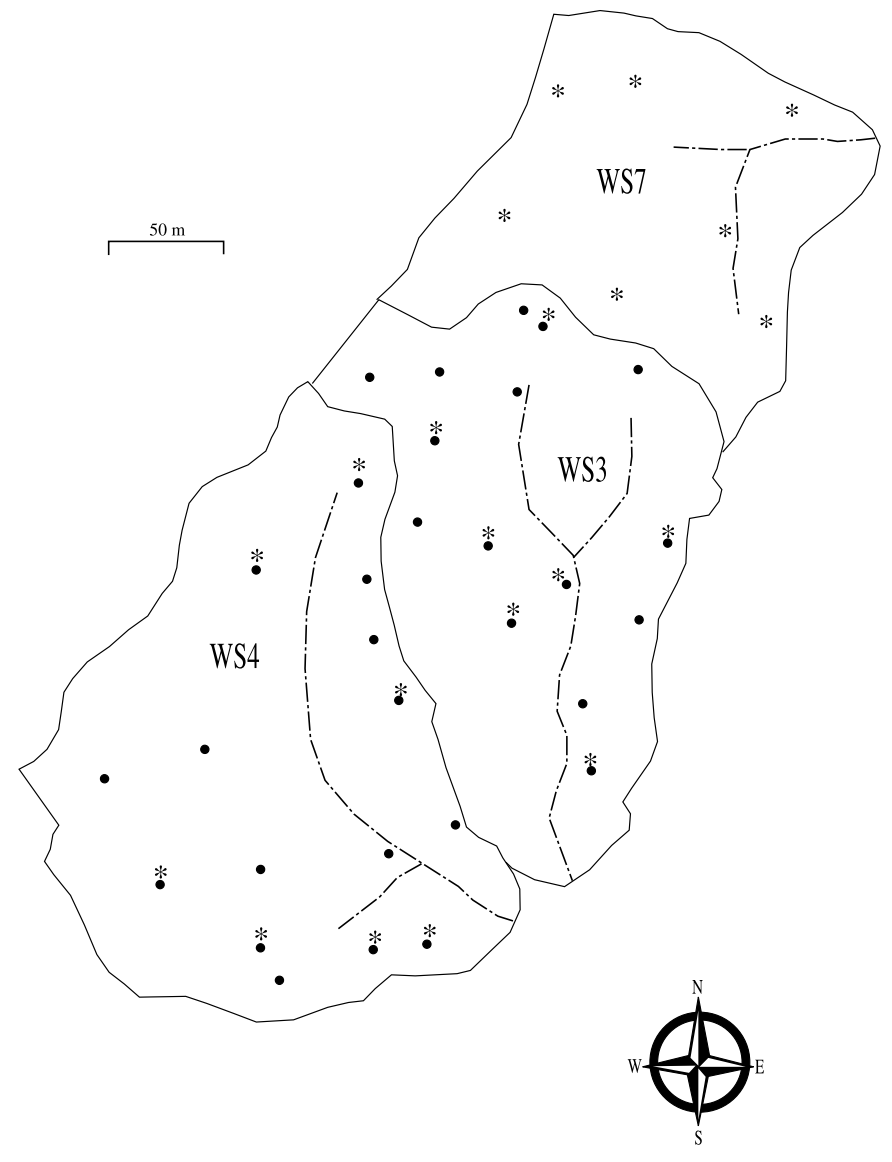

\section{Laboratory analyses}

Subsamples of soil from paired sample bags (one incubated and one brought back to the laboratory immediately after sampling) were extracted with $1 \mathrm{M} \mathrm{KCl}(10: 1, \mathrm{v} / \mathrm{w})$ and analyzed for $\mathrm{NH}_{4}{ }^{+}$ with an Orion 720A pH/ISE meter ${ }^{2}$ and $\mathrm{NH}_{4}{ }^{+}$electrode. Concentrations of $\mathrm{NH}_{4}{ }^{+}$in all samples were well above the detection limit of $0.01 \mathrm{ppm} \mathrm{NH}_{4}{ }^{+}-\mathrm{N}$ and well within the upper detection limit of $1400 \mathrm{ppm} \mathrm{NH}_{4}{ }^{+}-\mathrm{N}$. Separate subsamples were extracted with deionized $\mathrm{H}_{2} \mathrm{O}\left(10: 1\right.$, v/w) and analyzed for $\mathrm{NO}_{3}{ }^{-}$with an Orion $720 \mathrm{~A} \mathrm{pH} / \mathrm{ISE}$ meter and $\mathrm{NO}_{3}{ }^{-}$and reference electrodes. Separate extractions for $\mathrm{NO}_{3}{ }^{-}$were required to avoid interference of the $\mathrm{NO}_{3}^{-}$signal caused by high concentrations of $\mathrm{Cl}^{-}$in $1 \mathrm{M} \mathrm{KCl}$ extracts. As with $\mathrm{NH}_{4}{ }^{+}$, concentrations of $\mathrm{NO}_{3}{ }^{-}$in all samples were above the detection limit $\left(0.1 \mathrm{ppm} \mathrm{NO}_{3}{ }^{-} \mathrm{N}\right)$ and well within the upper detection limit of $140 \mathrm{ppm} \mathrm{NO}_{3}^{-}-\mathrm{N}$. Quality assurance procedures for both analyses included random repeat samples (which consistently indicated minimal signal drift) and recalibration for every hour of operation, producing an accuracy of $\pm 2 \%$. Net mineralization was calculated as incubated (buried) soil $\mathrm{NH}_{4}^{+}$plus
$\mathrm{NO}_{3}{ }^{-}$minus initial soil $\mathrm{NH}_{4}{ }^{+}$plus $\mathrm{NO}_{3}{ }^{-}$. Net nitrification was calculated as incubated soil $\mathrm{NO}_{3}^{-}$minus initial soil $\mathrm{NO}_{3}^{-}$. Pools of available $\mathrm{N}$ were determined as levels of extractable $\mathrm{NH}_{4}{ }^{+}$and $\mathrm{NO}_{3}{ }^{-}$in the initial soil sample. Relative nitrification was calculated as (net nitrification/net $\mathrm{N}$ mineralization) $\times 100$.

\section{Water chemistry}

Because of their relevance to interpreting responses of soil $\mathrm{N}$ transformation to $\mathrm{N}$ additions, we report $\mathrm{NO}_{3}^{-}$concentrations in stream and soil water during the 1993-1995 period. These samples are taken routinely by field personnel at the Timber and Watershed Laboratory, Parsons, W.V.; details for sampling protocols and chemical analyses are described in Adams et al. (1997). Briefly, stream water is taken as a grab sample at gauged weirs weekly for each of the watersheds. In addition to a suite of dissolved ions, these samples are analyzed for $\mathrm{NO}_{3}{ }^{-}$using automated colorimetry at the Timber and Watershed Laboratory. Soil water is taken once each month (when soil moisture is sufficient to produce samples) from zero-tension, porous ceramic plate lysimeters. Three lysimeters were placed at each of 15 locations throughout each of WS3 and WS4, one at the bottom of each of three soil horizons (A, B, and C) for a total of 45 lysimeters (Fig. 1). For simplicity, however, we include only data from the A horizon in this paper.

\section{Data analyses}

The statistical design of this study is an example of simple pseudoreplication, a common problem among watershed ecosystem studies, with each watershed representing an experimental condition with a sample size of one (Hurlbert 1984); thus, our data should be interpreted with that in mind. It is our contention that the effects we report are treatment effects, rather than pre-existing differences among watersheds, given the close similarities among watersheds in several "site" variables such as soil texture, soil organic matter, and extractable nutrients (Gilliam et al. 1994).

\section{Temporal patterns}

Monthly means of extractable soil $\mathrm{NH}_{4}{ }^{+}$and $\mathrm{NO}_{3}{ }^{-}$were compared among watersheds using analysis of variance and Duncan's multiple range test (SAS Institute Inc. 1990). Factors potentially influencing temporal patterns of soil $\mathrm{N}$ transformations were assessed with two multiple linear techniques. Multiple linear regression was used to examine the relationship between net nitrification rates and "environmental" variables, including extractable pools of inorganic $\mathrm{N}$, minimum, mean, and maximum ambient air temperature during the incubation period (based on data from the Timber and Watershed Laboratory adjacent to FEF), and preincubation (gravimetric) soil moisture, following the approach taken by Koopmans et al. (1995). Additionally, backward stepwise regression (Analytical Software 2000) was used to identify further which of the independent variables used in the multiple linear regression may have been more significantly correlated with net nitrification. This technique eliminates variables from the proposed model sequentially until all the variables remaining in the model produce $F$ statistics significant at a given probability level, in this case $P<$ 0.05 (Zar 1996).

\section{Spatial patterns}

We analyzed spatial patterns of $\mathrm{N}$ dynamics in two ways: (i) 3year means of soil water $\mathrm{NO}_{3}^{-}$concentrations for each of the lysimeter plots in WS3 and WS4 (note that lysimeters were not established in WS7) and (ii) 3-year monthly means of net nitrification and extractable $\mathrm{NO}_{3}{ }^{-}$and $\mathrm{NH}_{4}{ }^{+}$pools for each of the seven

\footnotetext{
${ }^{2}$ The use of trade, firm, or corporation names in this paper is for the information and convenience of the user, and constitutes neither endorsement nor approval by the U.S. Department of Agriculture or the Forest Service of any product or service to the exclusion of others that may be suitable.
} 
Table 1. Net $\mathrm{N}$ mineralization and nitrification and relative nitrification for selected forest sites of northeastern United States, Canada, and the Netherlands.

\begin{tabular}{|c|c|c|c|}
\hline Site & Mineralization & Nitrification & $\begin{array}{l}\text { Relative nitrification } \\
(\%)\end{array}$ \\
\hline \multicolumn{4}{|l|}{ West Virginia (this study) } \\
\hline Young control (WS7) & 126.2 & 114.9 & 91.0 \\
\hline Mature control (WS4) & 123.8 & 114.3 & 92.3 \\
\hline$+\mathrm{N}\left(35 \mathrm{~kg} \mathrm{~N} \cdot \mathrm{ha}^{-1} \cdot\right.$ year $\left.^{-1}\right)$ & 134.5 & 141.1 & 104.9 \\
\hline \multicolumn{4}{|l|}{ Adirondacks (Ohrui et al. 1999) } \\
\hline Upland hardwood & 106.9 & 29.0 & 27.1 \\
\hline Upland conifer & 82.4 & 2.4 & 2.9 \\
\hline \multicolumn{4}{|c|}{ Vermont (McNulty and Aber 1993) } \\
\hline Control & 16.0 & 0.0 & 0.0 \\
\hline$+\mathrm{N}\left(20 \mathrm{~kg} \mathrm{~N} \cdot \mathrm{ha}^{-1} \cdot\right.$ year $\left.^{-1}\right)$ & 54.3 & 2.1 & 3.9 \\
\hline \multicolumn{4}{|l|}{ Maine (Rustad et al. 1993) } \\
\hline Control & 75.0 & 3.0 & 4.0 \\
\hline$+\mathrm{N}\left(56 \mathrm{~kg} \mathrm{~N} \cdot \mathrm{ha}^{-1} \cdot \mathrm{year}^{-1}\right)$ & 59.0 & 16.0 & 27.1 \\
\hline \multicolumn{4}{|l|}{ Michigan (Ferrari 1999) } \\
\hline Old-growth hemlock-hardwood & 68.1 & 25.6 & 37.6 \\
\hline \multicolumn{4}{|l|}{ Michigan (Kim et al. 1996) } \\
\hline \multicolumn{4}{|l|}{ Uncut forest } \\
\hline Red oak & 29.8 & 0.0 & 0.0 \\
\hline Red pine & 13.4 & 0.4 & 3.0 \\
\hline \multicolumn{4}{|l|}{ Clearcut } \\
\hline Red oak & 67.0 & 0.9 & 1.3 \\
\hline Red pine & 26.9 & 3.3 & 12.3 \\
\hline \multicolumn{4}{|l|}{ Michigan (Mladenoff 1987) } \\
\hline \multicolumn{4}{|l|}{ Intact forest } \\
\hline Maple & 102.0 & 68.3 & 67.0 \\
\hline Hemlock & 88.7 & 27.4 & 31.0 \\
\hline \multicolumn{4}{|l|}{ Forest gap } \\
\hline Maple & 88.5 & 58.5 & 65.5 \\
\hline Hemlock & 107.3 & 69.8 & 64.6 \\
\hline \multicolumn{4}{|l|}{ Massachusetts (Aber et al. 1993) } \\
\hline \multicolumn{4}{|l|}{ Control } \\
\hline Pine & 75.1 & 25.4 & 33.8 \\
\hline Hardwood & 70.0 & 0.0 & 0.0 \\
\hline \multicolumn{4}{|l|}{$+\mathrm{N}\left(150 \mathrm{~kg} \mathrm{~N} \cdot \mathrm{ha}^{-1} \cdot\right.$ year $\left.^{-1}\right)$} \\
\hline Pine & 107.8 & 38.2 & 35.4 \\
\hline Hardwood & 92.2 & 2.4 & 2.6 \\
\hline \multicolumn{4}{|l|}{ Ontario (Devito et al. 1999) } \\
\hline Deciduous & 114.5 & 66.5 & 58.1 \\
\hline Conifer-hardwood & 139.1 & 18.6 & 13.3 \\
\hline \multicolumn{4}{|c|}{ Northeastern United States (Goodale and Aber 2001) } \\
\hline Old growth & 59.0 & 47.0 & 79.7 \\
\hline Logged & 57.0 & 29.0 & 50.9 \\
\hline Burned & 56.0 & 24.0 & 42.9 \\
\hline \multicolumn{4}{|c|}{ Northeastern United States (Lovett and Rueth 1999) } \\
\hline Beech & 15.7 & 5.6 & 35.7 \\
\hline Maple & 24.3 & 14.2 & 58.4 \\
\hline \multicolumn{4}{|c|}{ Netherlands (Tietema and Verstraten 1991) } \\
\hline Oak-beech & 115.0 & 69.0 & 60.0 \\
\hline
\end{tabular}
Rueth (1999), for which data are based on laboratory incubations $\left(\mu \mathrm{g} \mathrm{N} \cdot(\mathrm{g} \text { organic matter })^{-1} \cdot \mathrm{day}^{-1}\right)$.

incubation plots per watershed for all three watersheds. Separate approaches were warranted because the two data sets (soil water $\mathrm{NO}_{3}{ }^{-}$and nitrification or $\mathrm{N}$ pool data) represent different but complementary aspects of soil $\mathrm{N}$ dynamics.

\section{Soil water $\mathrm{NO}_{3}{ }^{-}$}

Soil water $\mathrm{NO}_{3}^{-}$concentrations were examined to test for possible relationships of soil $\mathrm{N}$ and vegetation. We have extensive data for tree and herb layer vegetation on each of the 15 plots on WS3 
Fig. 2. Seasonal patterns of (A) net $\mathrm{N}$ mineralization rates and (B) net nitrification for mineral soil (5-cm depth) from three watersheds of the Fernow Experimental Forest, Parsons, W.V. (FEF), from 1993 to 1995. Monthly means with the same letter are not significantly different among watersheds for that month at $P<0.10$. Values for a given month without letters are not significantly different among watersheds for that month. Arrows indicate approximate timing of additions of $\left(\mathrm{NH}_{4}\right)_{2} \mathrm{SO}_{4}$ to WS3 (see Methods).
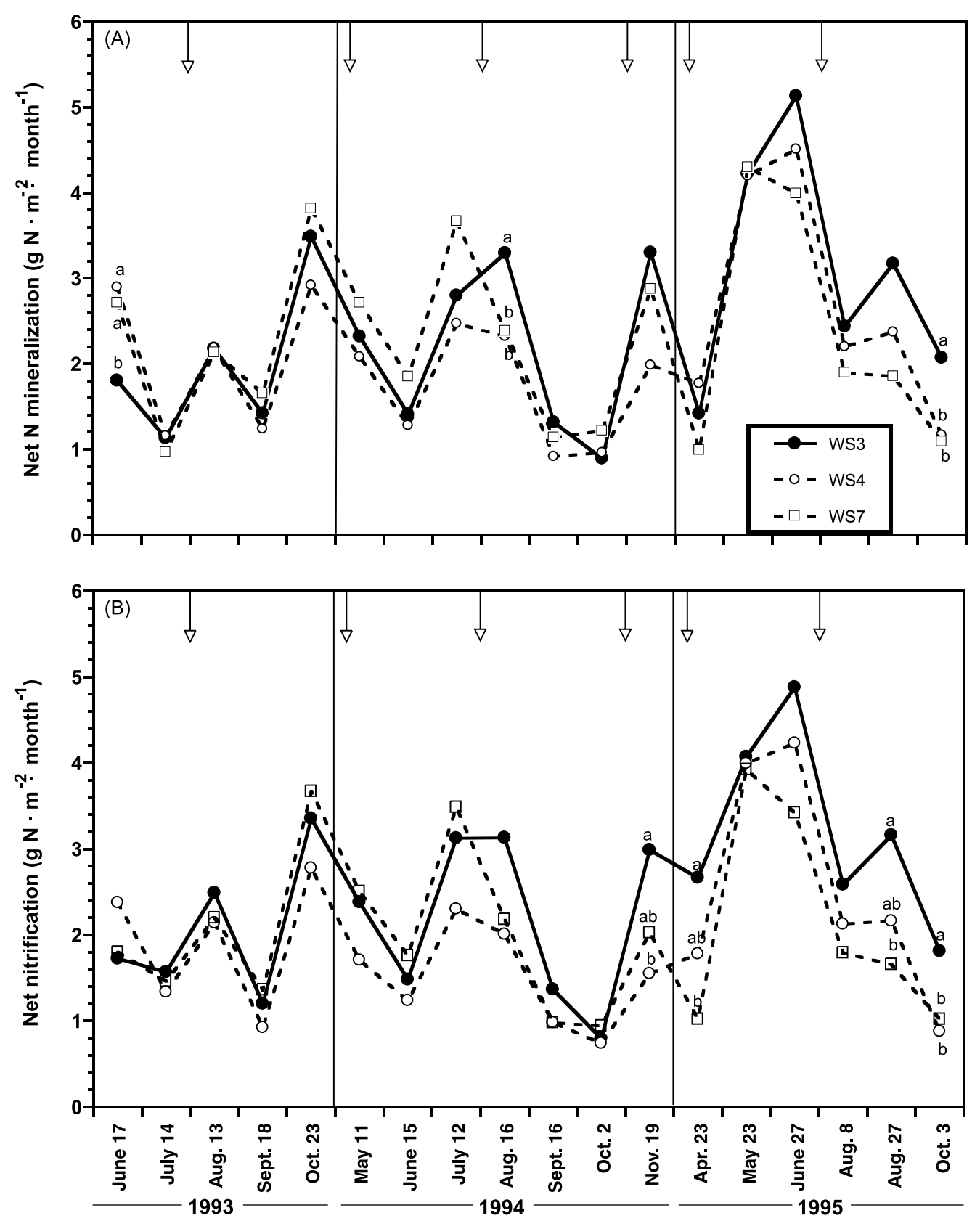

and WS4. Adjacent to each lysimeter a permanent vegetation plot (circular $0.04 \mathrm{ha}$ ) was established, within which data on basal area and density of tree species and cover of herbaceous layer species were collected. Additional soil data from each of these plots included texture, organic matter, $\mathrm{pH}$, and extractable nutrients.

To test for potential effects of tree and herbaceous layer species composition on soil water $\mathrm{NO}_{3}^{-}$, we performed detrended correspondence analysis (DCA) (ter Braak 1990) on data for the woody overstory (basal area and density of live stems $\geq 2.5 \mathrm{~cm}$ diameter at $1.3 \mathrm{~m}$ in height) and herbaceous layer (vascular plants $\leq 1 \mathrm{~m}$ in height) from plots adjacent to each of the 15 lysimeters in WS3 and WS4 (Gilliam et al. 1995).
Results of DCA were generated as composite graphs combining (i) axis scores (DCA axes 1 and 2) of sample plots and important tree and herb layer species and (ii) mean soil water $\mathrm{NO}_{3}{ }^{-}$concentrations next to each appropriate sample plot in ordination space for WS3 and WS4. The number of points in ordination space represents the number of plots for which there are both $\mathrm{N}$ data and vegetation data. Thus, there are 15 points for soil water $\mathrm{NO}_{3}{ }^{-}$data, with a separate DCA run for each figure.

Like other ordination techniques, DCA reduces species data to linear axes that best explain patterns of variation in composition (Kent and Coker 1992; Barbour et al. 1999). The result is an ordination diagram that locates sample plots relative to each other such 
Fig. 3. Seasonal patterns of (A) extractable $\mathrm{NH}_{4}{ }^{+}-\mathrm{N}$ pools and (B) extractable $\mathrm{NO}_{3}{ }^{-}-\mathrm{N}$ pools in mineral soil (5-cm depth) from three watersheds of the FEF for the years 1993-1995. Statistical differences are indicated as described in Fig. 2. Arrows indicate approximate timing of additions of $\left(\mathrm{NH}_{4}\right)_{2} \mathrm{SO}_{4}$ to WS3 (see Methods).
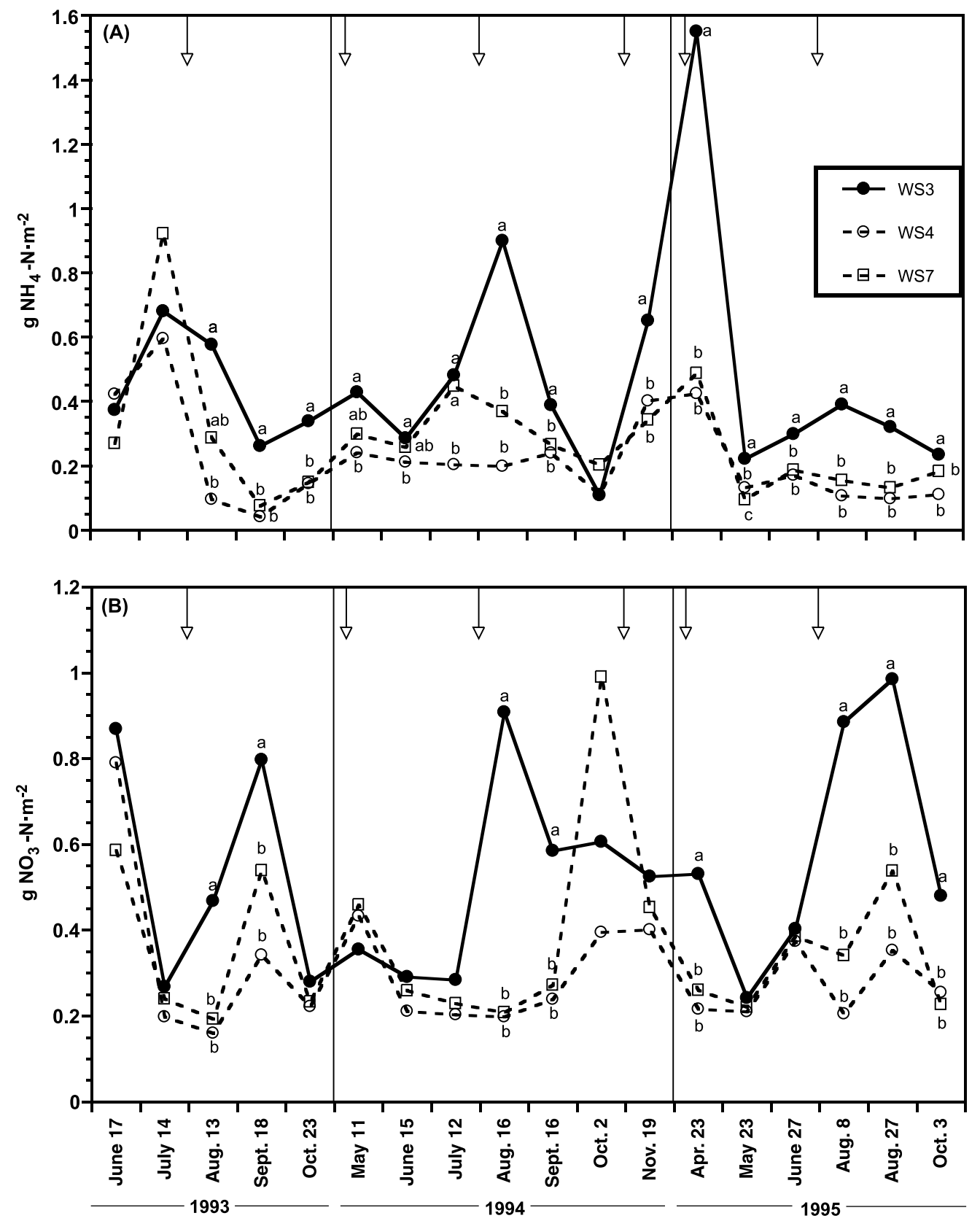

that the distance between plots in ordination space is a measure of dissimilarity in species composition (i.e., shorter distances indicates more similar composition). In addition, DCA allows the spatial patterns of occurrence of individual species to be determined. Locations of individual species are displayed in the same ordination space as the plots, indicating their position along axes gradients. Thus, if species composition is important in explaining spatial patterns of soil $\mathrm{N}$ dynamics, then plots with similar concentrations of soil water $\mathrm{NO}_{3}{ }^{-}$should have axis scores that locate them close together in ordination space. If particular species are associated with this relationship (e.g., plots with high or low soil water $\mathrm{NO}_{3}{ }^{-}$ concentrations), then the species' location on the graph will indicate that. Potential associations of $\mathrm{N}$ dynamics with species com- position were then tested with Spearman rank correlation (Analytical Software 2000) of soil water $\mathrm{NO}_{3}^{-}$(using 3-year means, 19931995) versus DCA axis 1 scores on a plot basis.

Net nitrification and factors and indices of $\mathrm{N}$ availability

Degrees and patterns of spatial variation of net nitrification and other variables related to $\mathrm{N}$ dynamics in watershed soils were assessed based on values for the seven incubation plots within each watershed. For nitrification, available inorganic N pools, and soil moisture, these values represent 3-year means for the study for each plot. For other variables, including total soil $\mathrm{N}$, soil $\mathrm{C} / \mathrm{N}$, and litter $\mathrm{N}$, these values were based on previous sampling (Gilliam et al. 1996). 
Fig. 4. $\mathrm{NH}_{4}{ }^{+}$and $\mathrm{NO}_{3}{ }^{-}$pools for soils of WS3 (treated), WS4 (untreated), and WS7 (untreated). Values are means of monthly values from 1993 to 1995. Bars with the same letter are not significantly different among watersheds $(P>0.05)$.

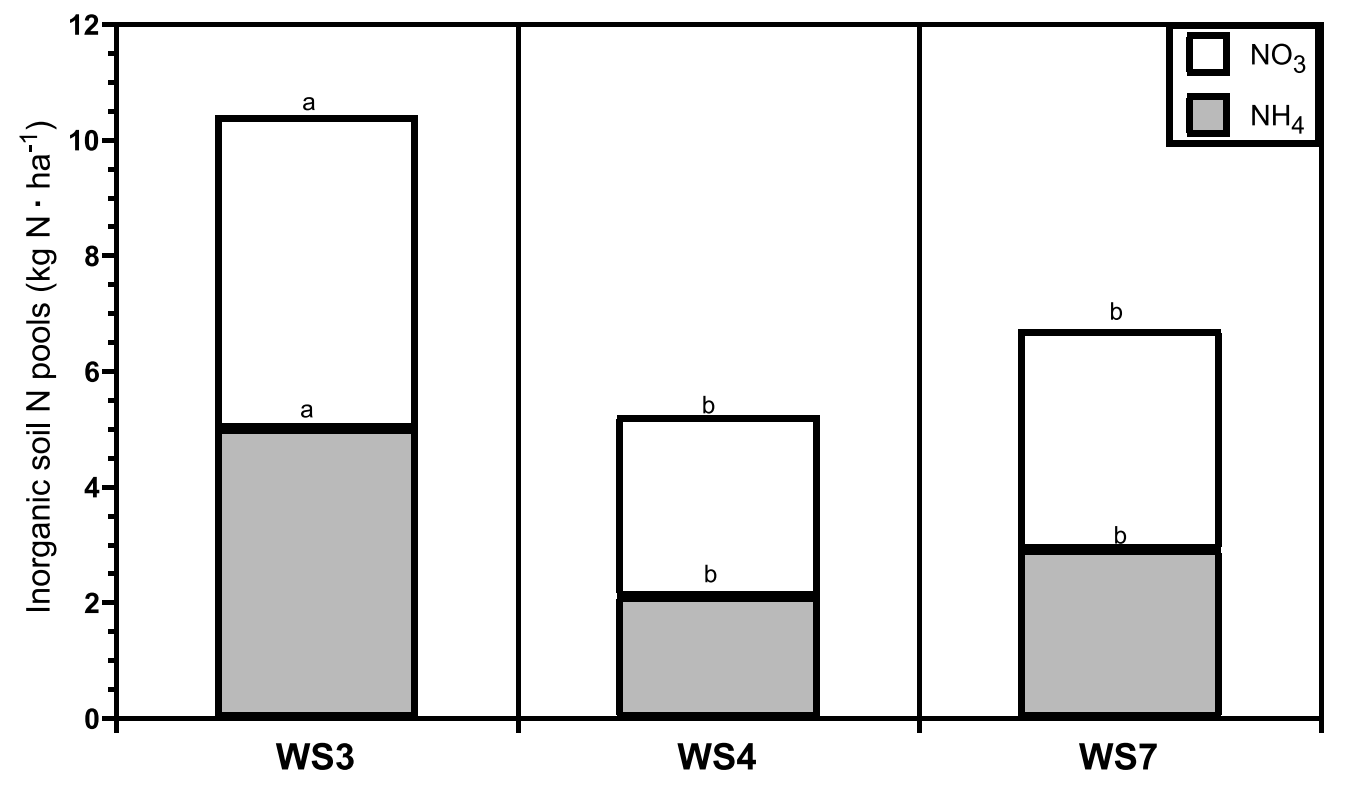

Table 2. Summary of regression analyses of seasonal patterns of net nitrification for study watersheds at FEF and for all data combined (monthly means averaged across all three watersheds): (A) multiple linear regression and (B) multiple regression using backward stepwise procedure, wherein variables significantly accounting for variability in the model at $P<0.05$ are listed with their coefficients.

\begin{tabular}{llll}
\hline (A) Multiple regression. & & \\
\hline Watershed & $F$ & $r^{2}$ & $P$ \\
\hline WS3 & 2.40 & 0.36 & 0.12 \\
WS4 & 4.79 & 0.60 & 0.02 \\
WS7 & 6.80 & 0.70 & 0.006 \\
All watersheds & 6.91 & 0.70 & 0.007 \\
\hline
\end{tabular}

(B) Multiple regression with backward stepwise procedure.

\begin{tabular}{lll}
\hline Watershed & Final model & \\
\hline WS3 & Net nitrification $=-4.88+0.15 T_{\text {mean }}+0.16 M$ & $r^{2}$ \\
WS4 & Net nitrification $=-6.82-2.43 \mathrm{NH}_{4}+0.14 T_{\max }+0.19 M$ & 0.38 \\
WS7 & Net nitrification $=-5.23-1.36 T_{\text {min }}+2.72 T_{\text {mean }}-1.19 T_{\max }+0.13 M$ & 0.66 \\
All & Net nitrification $=-5.20+0.16 T_{\text {mean }}+0.16 M$ & 0.72 \\
\hline
\end{tabular}

Note: See Methods for further details. Multiple regression model and original model for backward stepwise procedure: net nitrification $=\mathrm{NH}_{4}$ pool + $\mathrm{NO}_{3}$ pool $+T_{\text {min }}+T_{\text {mean }}+T_{\text {max }}+M$, where $T$ is temperature and $M$ is moisture.

Two approaches were used for these analyses. First, to provide a quantitative assessment of spatial variability, we determined coefficients of variation $(\mathrm{CVs})$ (calculated as (variance/mean) $\times 100)$ for means of several variables by watershed, in combination with analyses of variance to assess significant differences among watersheds. Variables included in this analysis were net nitrification, extractable $\mathrm{NH}_{4}{ }^{+}$and $\mathrm{NO}_{3}{ }^{-}$, tissue $\mathrm{N}$ concentration of Viola rotundifolia (an indicator species found in all 21 sample plots), litter $\mathrm{N}$, total soil $\mathrm{N}, \mathrm{N} / \mathrm{P}$ ratio of $\mathrm{V}$. rotundifolia (indicating $\mathrm{N}$ vs. $\mathrm{P}$ limitation; see Koerselman and Meuleman 1996), and soil C/N ratio. Second, we determined Pearson product-moment correlation coefficients (Analytical Software 2000) among variables to suggest spatial cause-and-effect relationships regarding net nitrification in watershed soils and examine possible effects of $\mathrm{N}$ additions on these relationships. Because of this, we performed analyses for each watershed separately. However, we were also interested in these relationships on the landscape scale and performed correlation analysis on all watersheds combined. Variables included in these analyses were the same for the CV comparisons, with the exception that soil moisture was included, but N/P ratios were not.

\section{Results and discussion}

\section{Net nitrification relative to net $\mathbf{N}$ mineralization}

For the 3-year study period, mean annual net $\mathrm{N}$ mineralization was $134.5,123.8$, and $126.2 \mathrm{~kg} \mathrm{~N} \cdot \mathrm{ha}^{-1} \cdot$ year $^{-1}$ for WS3, WS4, and WS7, respectively; mean annual net nitrification was $141.1,114.3$, and $114.9 \mathrm{~kg} \mathrm{~N} \cdot \mathrm{ha}^{-1} \cdot$ year $^{-1}$, respectively (Table 1). Relative nitrification (the percentage of mineralized $\mathrm{N}$ that becomes nitrified) for WS3, WS4, and WS7 was 105, 92, and 91\%, respectively (Table 1). These high rates of nitrification at FEF suggest that $\mathrm{N}$ cycling in these soils is dominated by $\mathrm{NO}_{3}{ }^{-}$rather than $\mathrm{NH}_{4}{ }^{+}$; the latter is more often the case in forests with acidic soils (Binkley 
Fig. 5. Volume-weighted monthly means of stream water $\mathrm{NO}_{3}{ }^{-}-\mathrm{N}$ from WS3 (treated), WS4 (untreated), and WS7 (untreated) from 1993 to 1995. Arrows indicate approximate timing of additions of $\left(\mathrm{NH}_{4}\right)_{2} \mathrm{SO}_{4}$ to WS3 (see Methods).

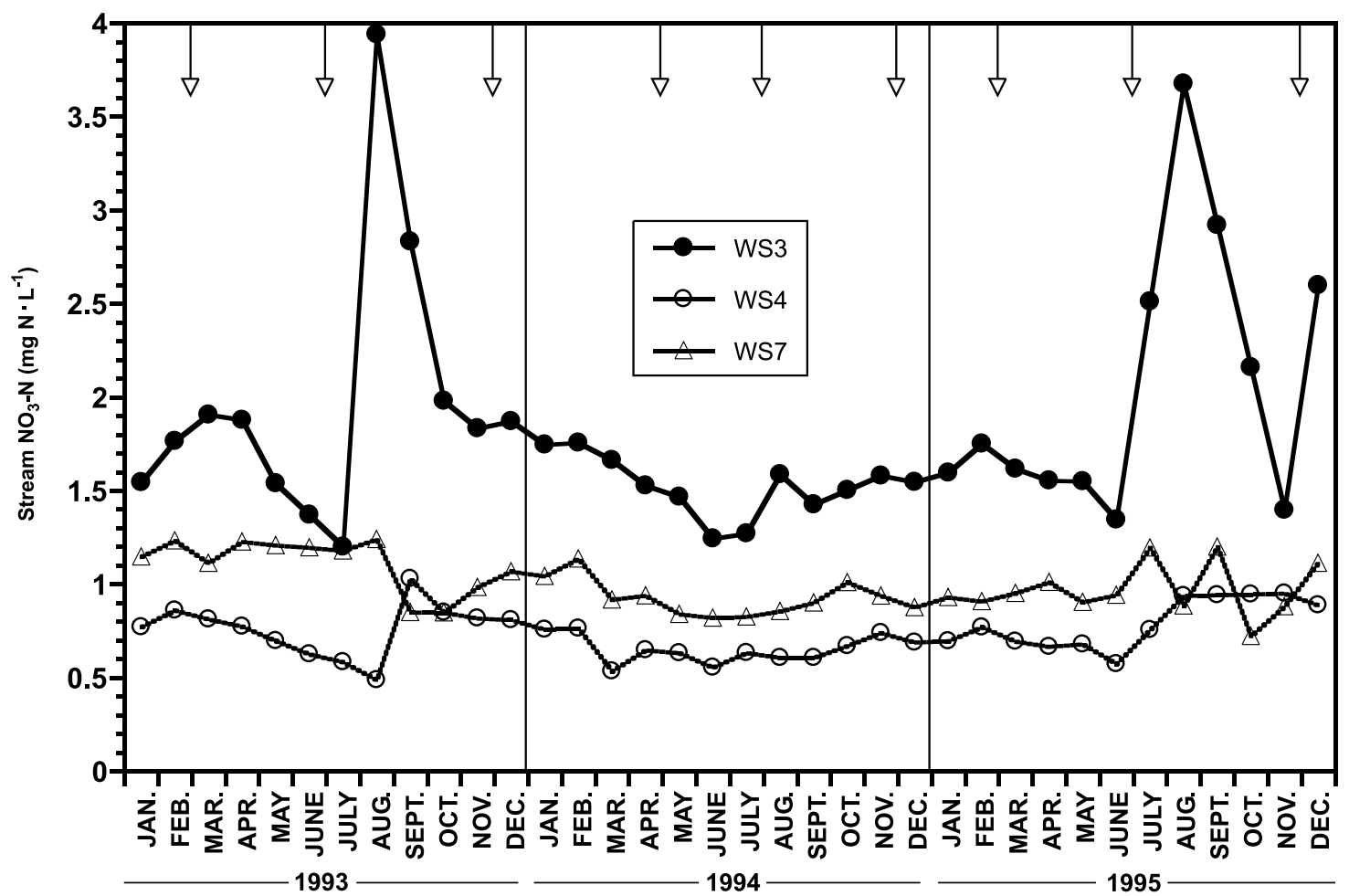

1986; Aber and Melillo 1991). Nitrate-dominated N cycling was one of several predictions of Aber et al. (1989) to be a consequence of the shift of forest soils from $\mathrm{N}$ limitation to $\mathrm{N}$ saturation. The cause of such high rates of nitrification at FEF is not clear. Atmospheric deposition of $\mathrm{N}$ has been shown to be high at this site (Gilliam and Adams 1996) and has likely contributed to this. However, recent evidence suggests that $\mathrm{N}$ deposition alone is a poor predictor of the onset of $\mathrm{N}$ saturation (Lovett et al. 2000).

One view of $\mathrm{N}$ limitation is that low soil $\mathrm{NH}_{4}{ }^{+}$limits access of nitrifying bacteria to $\mathrm{NH}_{4}^{+}$, because they are less competitive than are plant roots (uptake) and heterotrophic microbes (immobilization) (Vitousek et al. 1982; Binkley 1986; Johnson and Ball 1990), although this view has been challenged in more recent literature (Johnson 1992). It is clear, however, that as availability of $\mathrm{N}$ increases, the relative amount of mineralized $\mathrm{N}$ that is nitrified should also increase, consistent with what has occurred at FEF. Values of relative nitrification for sites other than FEF range from $0 \%$ (McNulty and Aber 1993; Aber et al. 1993; Kim et al. 1996) to $\sim 80 \%$ (Mladenoff 1987; Tietema and Verstraten 1991; Goodale and Aber 2001).

Comparisons across sites (Table 1) provide several observations about $\mathrm{N}$ transformations in forest soils concerning the relative importance of net nitrification. Several studies have shown that stand type (and consequently litter quality and quantity) can profoundly influence both net $\mathrm{N}$ mineralization and relative nitrification, with values of both being generally higher for hardwood stands than for conifer stands (Mladenoff 1987; Kim et al. 1996; Ohrui et al. 1999; Lovett and Rueth 1999). This generalization does not hold true for all studies, however, emphasizing the importance of stand (land-use) history (Aber et al. 1993; Goodale and Aber 2001). Forest disturbance generally increases mineralization and relative nitrification, but this can also be site dependent (Mladenoff 1987; Kim et al. 1996). Experimental N additions tend to increase relative nitrification measurably (McNulty and Aber 1993; Rustad et al. 1993; Aber et al. 1993).

\section{Temporal patterns: watershed comparisons}

Net mineralization was significantly higher on treatment WS3 than control WS4 and WS7 for only 2 of the 18 monthly periods (Fig. 2A). Seasonal patterns for net nitrification were similar to those for net $\mathrm{N}$ mineralization, although there were more monthly periods when nitrification exhibited a significant treatment effect, especially toward the end of the study period (Fig. 2B). Monthly rates and temporal patterns of $\mathrm{N}$ mineralization and nitrification at FEF (Figs. 2A and 2B) contrast sharply with those of Aber et al. (1993), who studied the effects of experimental $\mathrm{N}$ additions (50 and $150 \mathrm{~kg} \mathrm{~N} \cdot \mathrm{ha}^{-1} \cdot \mathrm{year}^{-1}$ ) on a 65 -year-old red pine stand and an 80-year-old mixed hardwood stand at the Harvard Forest, Massachusetts. They found net $\mathrm{N}$ mineralization and nitrification rates in the pine stand ranged from 0 to $\sim 2 \mathrm{~g} \mathrm{~N} \cdot \mathrm{m}^{-2} \cdot \mathrm{month}^{-1}$ and from 0 to $0.8 \mathrm{~g} \mathrm{~N} \cdot \mathrm{m}^{-2} \cdot \mathrm{month}^{-1}$, respectively; rates in the hardwood stand ranged from 0 to $1 \mathrm{~g} \mathrm{~N} \cdot \mathrm{m}^{-2} \cdot \mathrm{month}^{-1}$ and 0 to $0.1 \mathrm{~g} \mathrm{~N} \cdot \mathrm{m}^{-2} \cdot \mathrm{month}^{-1}$, respectively, for all treatments. Rates for both control and treatment watersheds at FEF greatly exceeded these values, generally ranging from 1 to $5 \mathrm{~g} \mathrm{~N} \cdot \mathrm{m}^{-2} \cdot \mathrm{month}^{-1}$ for both net $\mathrm{N}$ mineralization and nitrification (Figs. 2A and 2B).

Monthly means of $\mathrm{NH}_{4}^{+}$pools were significantly higher on treatment WS3 than on either WS7 or WS4 or both for 
Fig. 6. Mean soil water $\mathrm{NO}_{3}{ }^{-} \mathrm{N}$ (in $\mathrm{mg} \mathrm{N} \cdot \mathrm{L}^{-1}$ ) from 1993 to 1995 for WS3 (treated) and WS4 (untreated). Values below points are from 15 zero-tension lysimeters per watershed. Note that one lysimeter (No. 8) failed to operate properly in WS3.

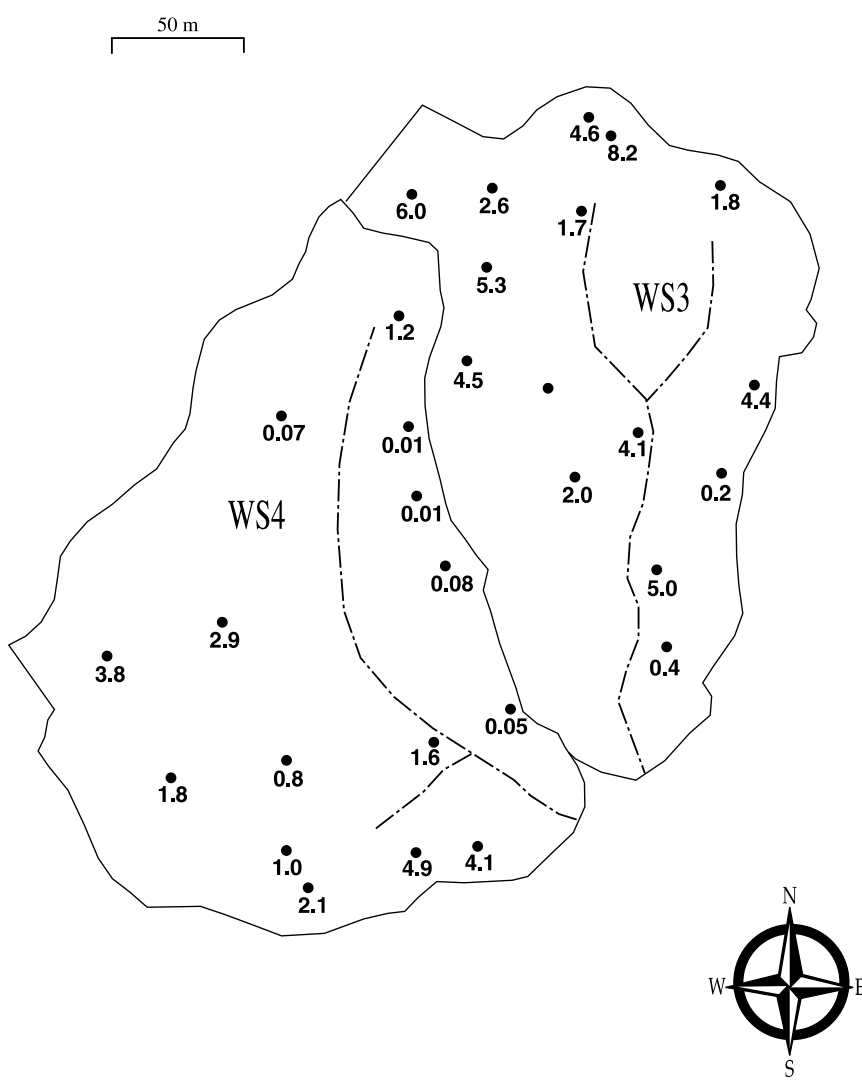

15 of the 18 months of the study period (Fig. 3A). Means of $\mathrm{NO}_{3}{ }^{-}$pools were significantly higher on WS3 than on either WS7 or WS4 or both for 8 of the 18 sample months of the study period (Fig. 3B). Temporal patterns of $\mathrm{N}$ pools in WS3 were generally consistent with the timing of $\mathrm{N}$ additions to the watershed. Aerial applications of $\left(\mathrm{NH}_{4}\right)_{2} \mathrm{SO}_{4}$ (see Methods section) were made in March, July, and November at the rates of $7.1,21.2$, and $7.1 \mathrm{~kg} \mathrm{~N} \cdot \mathrm{ha}^{-1}$, respectively, during the study. Thus, the prominent peaks in $\mathrm{NH}_{4}{ }^{+}$ in August 1994 and April 1995 were synchronous with July and March applications, respectively (Fig. 3A). Similar peak responses were seen for $\mathrm{NO}_{3}{ }^{-}$, including August-September 1993 and 1994, and April and August-September 1995 (Fig. 3B).

In $\mathrm{N}$-limited forests, available $\mathrm{N}$ pools usually approach zero during the growing season because of high rates of $\mathrm{N}$ uptake by plants exhibiting maximum growth rates (Stoddard 1994). Although available $\mathrm{N}$ pools at FEF were generally their lowest during the growing season, $\mathrm{N}$ pools even on control watersheds (WS7 and WS4) remained well above zero during the growing season, suggesting mineralization and nitrification rates exceed uptake by plants. Experimental $\mathrm{N}$ inputs at FEF have increased pools of available $\mathrm{N}$ in the mineral soil of WS3 (Figs. 3A and 3B). Higher $\mathrm{NH}_{4}{ }^{+}$in soils of treated WS3 was certainly an expected response, given that $\mathrm{N}$ was added as $\mathrm{NH}_{4}{ }^{+}$. Higher $\mathrm{NO}_{3}{ }^{-}$in WS3 soils, however, likely resulted from a combination of nitrification of both $\mathrm{NH}_{4}^{+}$added as $\left(\mathrm{NH}_{4}\right)_{2} \mathrm{SO}_{4}$ and $\mathrm{NH}_{4}{ }^{+}$ rapidly mineralized from organic matter. This suggests a rapid movement of $\mathrm{N}$ through an $\mathrm{N}$-saturated system. The lag response for $\mathrm{NO}_{3}{ }^{-}$pools (Fig. 3B) was probably related to the time required for microbial oxidation of added $\mathrm{NH}_{4}{ }^{+}$. Thus, extractable $\mathrm{N}$ pools appear to be sensitive to further inputs of $\mathrm{N}$ under $\mathrm{N}$ saturated conditions.

Total inorganic pools of $\mathrm{N}\left(\mathrm{NH}_{4}{ }^{+}+\mathrm{NO}_{3}{ }^{-}\right)$averaged over the entire study period were $10.4 \mathrm{~kg} \mathrm{~N} \cdot \mathrm{ha}^{-1}$ for WS3, which was significantly higher than pools for WS4 and WS7 (5.1 and $6.7 \mathrm{~kg} \mathrm{~N} \cdot \mathrm{ha}^{-1}$, respectively); means for WS4 and WS7 were not significantly different from each other (Fig. 4). Mean extractable $\mathrm{NO}_{3}{ }^{-}$pools were $>50 \%$ of total extractable inorganic $\mathrm{N}$ for all watersheds.

\section{Temporal patterns: factors influencing net nitrification}

Multiple regression and stepwise procedures demonstrated that the temporal patterns for net nitrification for untreated WS4 and WS7 (Fig. 2B; Table 2) were strongly influenced by environmental factors, particularly ambient temperature and soil moisture. Similar results were found when these were run for all three study watersheds combined (Table 2). Such relationships are certainly to be expected for a microbially mediated process such as nitrification (Yin 1992), although most studies describing these relationships are based on laboratory incubations (Emmer and Tietema 1990; Stark 1996; Niklinska et al. 1999). Thus, it is notable that results of this study demonstrate these relationships under ambient conditions at the larger scale of a functioning ecosystem. Using nonlinear regression, Tietema and Verstraten (1991) found highly significant relationships between mean ambient monthly temperature and in situ measurements of nitrification in a Dutch oak-beech forest.

Results of similar analyses for treated WS3 (Fig. 2B, Table 2) suggest that an important effect of excess $\mathrm{N}$ additions might be to affect the otherwise close relationship between soil microbes and the environmental conditions that influence their activity. In contrast to highly significant multiple linear regressions for the combination of all watersheds and for untreated watersheds alone, regressions of net nitrification on environmental variables were not significant for treated WS3 (Table 2), suggesting that $\mathrm{N}$ additions may alter the relationship between soil microbial populations and the ambient environment. Similar contrasts between high versus low $\mathrm{N}$ addition plots were reported by Koopmans et al. (1995) for conifer forests of the Netherlands. Using multiple linear regression models that compared nitrification to extractable $\mathrm{NH}_{4}{ }^{+}$and $\mathrm{NO}_{3}{ }^{-}, \mathrm{pH}$, moisture, and temperature, they found consistently lower $r^{2}$ values for the high $\mathrm{N}$ deposition plots than for ambient $\mathrm{N}$ and low $\mathrm{N}$ deposition plots (Koopmans et al. 1995). It is important to note that we are not suggesting that ambient temperature and moisture no longer influence the microbial activity that mediates soil $\mathrm{N}$ transformations under conditions of $\mathrm{N}$ saturation. Rather, we suggest that microbes in an $\mathrm{N}$-saturated soil system complex may become more responsive to other factors, such as the simulated, episodically elevated inputs of $\mathrm{N}$ in this study.

Temporal increases in concentrations of stream water $\mathrm{NO}_{3}^{-}$for WS3 were generally synchronous with $\mathrm{N}$ additions, with stream $\mathrm{NO}_{3}^{-}$consistently higher for treated WS3 
Fig. 7. Detrended correspondence analysis (DCA) of overstory species in (A) WS3 and (B) WS4. Each point represents a sample plot adjacent to a lysimeter, with corresponding values for mean soil water $\mathrm{NO}_{3}^{-}\left(\mathrm{mg} \mathrm{NO}_{3}^{-}-\mathrm{N} \cdot \mathrm{L}^{-1}\right)$ for each lysimeter. Spatial occurrence is indicated by an " $\mathrm{x}$ " for the more important species: sugar maple (ACSA), beech (FAGR), yellow poplar (LITU), black cherry (PRSE), and northern red oak (QURU).
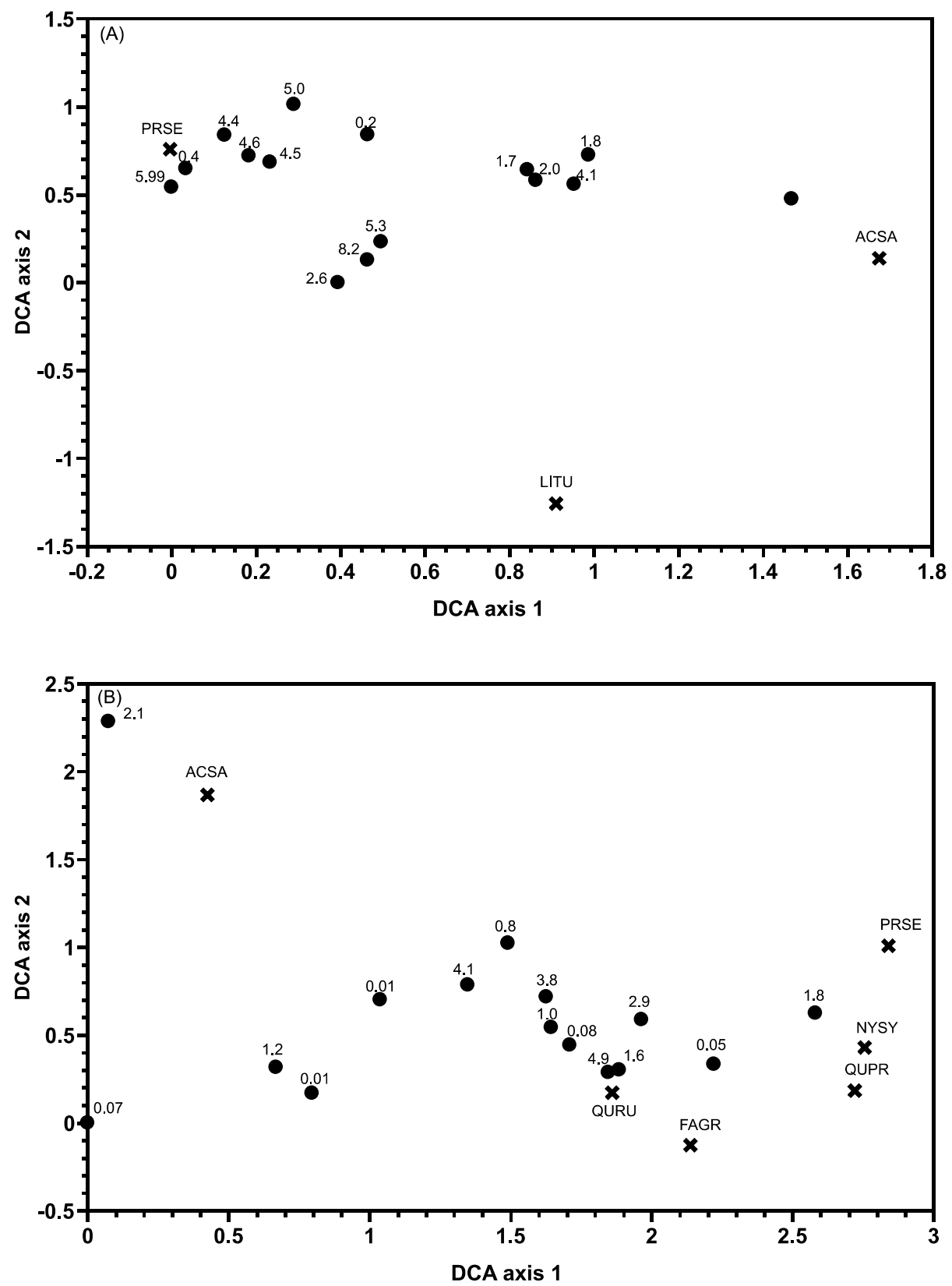

than either of untreated WS4 or WS7 (Fig. 5). Increases in $\mathrm{NO}_{3}{ }^{-}$concentrations from July to August in all 3 years, especially 1993 and 1995, followed the large July additions of $\mathrm{N}$ to WS3 (about $21 \mathrm{~kg} \mathrm{~N} \cdot \mathrm{ha}^{-1}$ ). Such patterns were found for neither WS7 nor WS4 for any year of the study.

Accordingly, we suggest that the one of the more compelling results of excess $\mathrm{N}$ deposition to forest ecosystems is that an appreciable amount of inorganic $\mathrm{N}$ bypasses the organic cycling and reprocessing of $\mathrm{N}$ within the forest ecosystem. In other words, $\mathrm{N}$ deposition at elevated rates (here in the form of $\mathrm{NH}_{4}^{+}$) may exceed the $\mathrm{N}$ demands of plant uptake and microbial immobilization, thereby increasing
$\mathrm{NH}_{4}{ }^{+}$availability for nitrifying bacteria. Similarly, a considerable amount of atmospheric deposition of highly mobile $\mathrm{NO}_{3}{ }^{-}$to $\mathrm{N}$-saturated forests may pass through soils being taken up by neither microbes nor plant roots, thereby rapidly reaching streams. Such a phenomenon has been documented using analyses of natural isotope ratios of ${ }^{15} \mathrm{~N}$ and ${ }^{18} \mathrm{O}$ in $\mathrm{NO}_{3}{ }^{-}$in rain, snow, and springwater of forest stands of Germany (Durka et al. 1994; Hedin 1994).

In our study, the coincidence of the timing of $\left(\mathrm{NH}_{4}\right)_{2} \mathrm{SO}_{4}$ additions and notable increases in $\mathrm{N}$ mineralization, nitrification, extractable soil $\mathrm{N}$ pools, and $\mathrm{N}$ in streams (Figs. 2, 3, and 5) suggests that a similar response is occurring in the 
Fig. 8. Detrended correspondence analysis (DCA) of herbaceous layer species in (A) WS3 and (B) WS4. Each point represents a sample plot adjacent to a lysimeter, with corresponding values for mean soil water $\mathrm{NO}_{3}^{-}\left(\mathrm{mg} \mathrm{NO}_{3}^{-}-\mathrm{N} \cdot \mathrm{L}^{-1}\right)$ for each lysimeter. Spatial occurrence is indicated by an " $\mathrm{x}$ " for the more important species: striped maple (ACPE), stinging nettle (LACA), Christmas fern (POAC), Viola spp. (VIOL), greenbrier (SMRO), and hillside blueberry (VAVA).
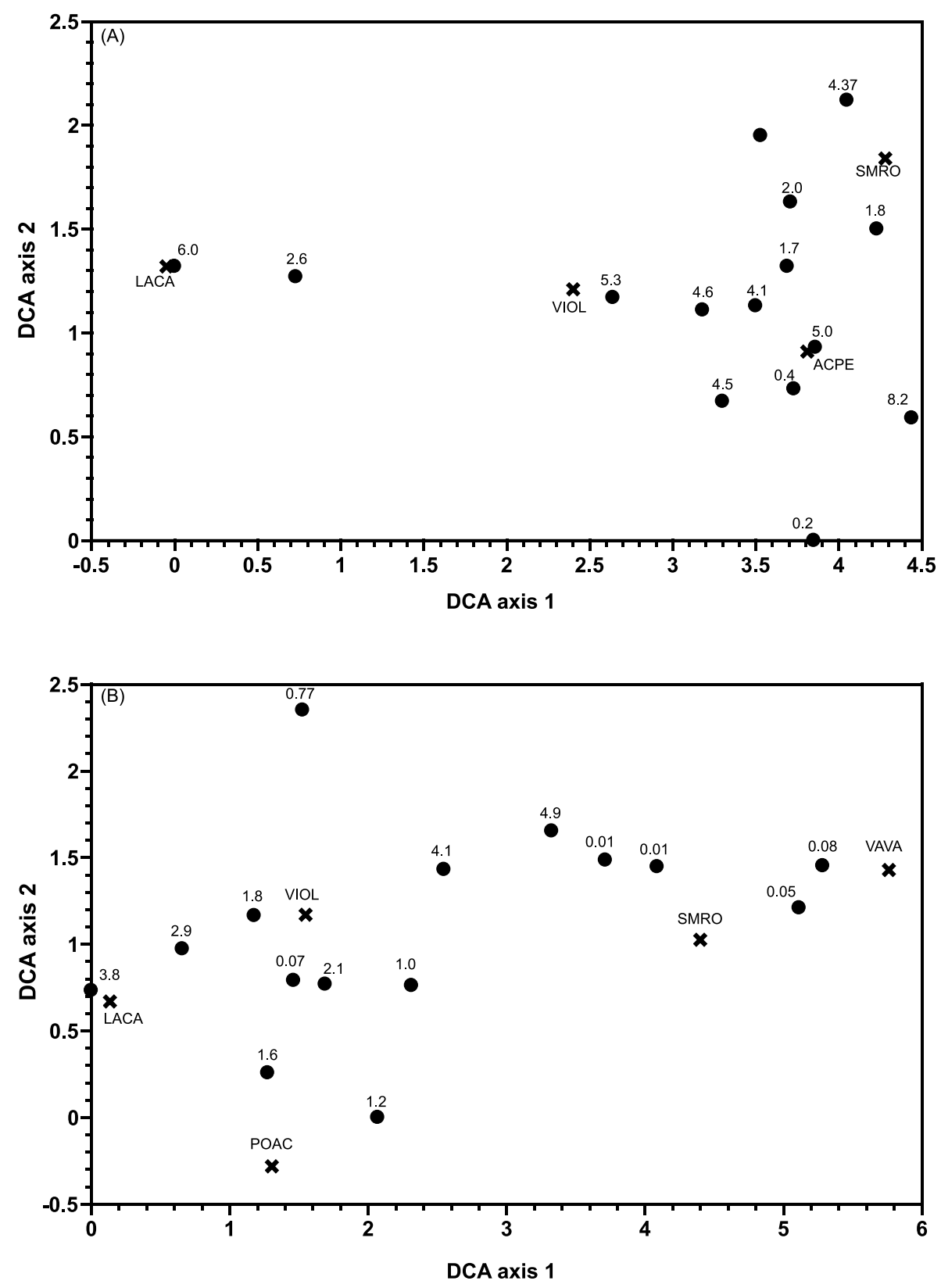

treated watershed at FEF. Consequently, the biotic processes responsible for regulating $\mathrm{N}$ dynamics over time in forest ecosystems may be altered under conditions of $\mathrm{N}$ saturation.

\section{Spatial patterns: soil water $\mathrm{NO}_{3}^{-}$}

Soil water $\mathrm{NO}_{3}{ }^{-}$ranged from 0.2 to $8.2 \mathrm{mg} \mathrm{NO}{ }_{3}^{-}-\mathrm{N} \cdot \mathrm{L}^{-1}$ in WS3 and from 0.01 to $4.9 \mathrm{mg} \mathrm{NO}{ }^{-}-\mathrm{N} \cdot \mathrm{L}^{-1}$ in WS4 (Fig. 6). (Note that one lysimeter in WS3, No. 8, failed to operate properly.) Coefficients of variation of the mean of all lysimeter plots were 100 versus $63 \%$ for WS4 and WS3, respectively. Concentration for WS3 was $3.6 \pm 0.6 \mathrm{mg} \mathrm{NO}_{3}^{-}$$\mathrm{N} \cdot \mathrm{L}^{-1}$ (mean $\left.\pm \mathrm{SE}\right)$, significantly higher $(P<0.05)$ than $1.6 \pm$
$0.4 \mathrm{mg} \mathrm{NO}{ }_{3}^{-}-\mathrm{N} \cdot \mathrm{L}^{-1}$ for WS4, suggesting that $\mathrm{N}$ additions to WS3 have both increased concentrations of soil water $\mathrm{NO}_{3}^{-}$ and reduced spatial variability of soil $\mathrm{N}$ processing. Part of the spatial variation in soil water $\mathrm{NO}_{3}^{-}$in both WS3 and WS4 appears to be related to aspect, particularly for WS4. Even in WS3, plots with the lowest concentrations of soil water $\mathrm{NO}_{3}{ }^{-}$were generally associated with higher elevation areas along west-facing slopes (Fig. 6). In WS4, however, aspect-related differences were more pronounced, with soil water from south- to southwest-facing plots at barely detectable levels of $\mathrm{NO}_{3}^{-}$in contrast to appreciable levels elsewhere in the watershed (Fig. 6). 
Table 3. Soil and vegetation variables for south- to southwest-facing slopes (low $\mathrm{N}$ ) versus the rest of WS4 and $p$ values for $t$-test comparisons.

\begin{tabular}{llll}
\hline Variable & Low N Plots & Rest of WS4 & $p$ \\
\hline Soil texture $(\%)$ & & & \\
$\quad$ Sand & $66.7 \pm 2.2$ & $65.8 \pm 2.0$ & $\mathrm{~ns}$ \\
$\quad$ Silt & $20.6 \pm 1.3$ & $24.3 \pm 1.4$ & $\mathrm{~ns}$ \\
$\quad$ Clay & $12.7 \pm 1.1$ & $10.0 \pm 0.8$ & $<0.10$ \\
Cation exchange capacity (mequiv. $\left.\cdot 100 \mathrm{~g}^{-1}\right)$ & $4.0 \pm 0.1$ & $4.1 \pm 0.3$ & $\mathrm{~ns}$ \\
Exchangeable acidity $(\%)$ & $84.9 \pm 2.2$ & $77.2 \pm 1.4$ & $<0.05$ \\
pH & $4.85 \pm 0.14$ & $5.20 \pm 0.08$ & $<0.10$ \\
Organic matter $(\%)$ & $14.1 \pm 1.1$ & $13.7 \pm 0.6$ & $\mathrm{~ns}$ \\
Extractable nutrients $\left(\mu\right.$ equiv. $\left.\cdot \mathrm{g}^{-1}\right)$ & & & \\
Ca & $2.8 \pm 0.2$ & $5.4 \pm 0.4$ & $<0.01$ \\
$\mathrm{Mg}$ & $1.3 \pm 0.1$ & $1.6 \pm 0.1$ & $\mathrm{~ns}$ \\
$\mathrm{~K}$ & $1.9 \pm 0.3$ & $2.2 \pm 0.2$ & $\mathrm{~ns}$ \\
$\mathrm{P}$ & $0.37 \pm 0.05$ & $0.50 \pm 0.03$ & $<0.05$ \\
Herb layer tissue nutrients $(\%)$ & & & \\
Ca & $0.58 \pm 0.07$ & $0.80 \pm 0.09$ & $<0.10$ \\
$\mathrm{Mg}$ & $0.12 \pm 0.01$ & $0.26 \pm 0.02$ & $<0.001$ \\
$\mathrm{~K}$ & $0.85 \pm 0.10$ & $2.31 \pm 0.22$ & $<0.001$ \\
$\mathrm{P}$ & $0.10 \pm 0.001$ & $0.18 \pm 0.01$ & $<0.001$ \\
$\mathrm{~N}$ & $1.23 \pm 0.07$ & $2.26 \pm 0.10$ & $<0.001$ \\
Tree basal area $\left(\mathrm{m}^{2} \cdot \mathrm{ha}^{-1}\right)$ & $33.3 \pm 1.4$ & $39.3 \pm 2.6$ & $<0.10$ \\
Tree size $\left(\mathrm{cm}^{2} / \mathrm{stem}^{2}\right)$ & $316 \pm 28$ & $465 \pm 51$ & $<0.05$ \\
\hline $\mathrm{N}$ & & &
\end{tabular}

Note: Values are means \pm SEs. ns, not significantly different $(P>0.10)$.

The spatial pattern for soil water $\mathrm{NO}_{3}^{-}$in WS4 (Fig. 6) was observed also by Peterjohn et al. (1999). They hypothesized that such differences were the result of aspect-related differences in tree species composition, based on a division of WS4 into two areas (one with a southerly aspect and the other with an easterly aspect) and direct comparisons (south vs. east) of tree species composition. However, because plant communities are composed of species that exhibit a continuum of change (sensu Gleason 1939) in response to several environmental gradients (i.e., more than just aspect), a more appropriate analytical approach would be the multivariate one used here: DCA. This avoids the a priori assumption that aspect alone is the major controlling factor in species composition.

The predominant woody vegetation gradient for WS3 consisted of black cherry at the low end to sugar maple at the high end of axis 1 (Fig. 7A). Soil water $\mathrm{NO}_{3}^{-}$was not correlated (Spearman rank correlation analysis) with DCA axis 1 scores $\left(r_{\mathrm{S}}=0.24, P>0.10\right)$. The predominant tree species gradient for WS4 was one of sugar maple at the low end of DCA axis 1, with black cherry, blackgum (Nyssa sylvatica Marshall), and chestnut oak (Quercus prinus L.) at the high end, and northern red oak and American beech (Fagus grandifolia Ehrh.) near the middle (Fig. 7B). As with WS3, soil water $\mathrm{NO}_{3}{ }^{-}$in WS4 was not correlated with DCA axis 1 scores $\left(r_{\mathrm{S}}=0.06, P>0.10\right)$.

Peterjohn et al. (1999) further suggested that blackgum, beech, and dominant oak species (Quercus spp.) should be associated with areas of low $\mathrm{NO}_{3}{ }^{-}$in soil solution. However, results of DCA indicate a woody vegetation gradient in conflict with this prediction for WS4 (Fig. 7B). Again, soil water $\mathrm{NO}_{3}{ }^{-}$in WS4 did not appear to respond to the overstory vegetation gradient; thus, based on our data we must reject the hypothesis that spatial patterns of soil water $\mathrm{NO}_{3}{ }^{-}$on WS4 are controlled by spatial variation in tree species composition.

On WS3, soil water $\mathrm{NO}_{3}{ }^{-}$was not significantly correlated with DCA axis 1 for the herbaceous layer $\left(r_{\mathrm{S}}=-0.20, P>\right.$ $0.10)$, a gradient of stinging nettle at the low end to greenbrier (Smilax rotundifolia L.) and seedlings of striped maple (Acer pensylvanicum L.) at the high end of axis 1, with species of Viola being intermediate (Fig. 8A). Axis 1 of the DCA for the herbaceous layer of WS4 was a gradient of nettle, species of Viola, and Christmas fern (Polystichum acrostichoides (Michx.) Schott.) on moist, less acidic soils to greenbrier and hillside blueberry (Vaccinium vacillans Aiton.) on exposed, more acidic soils (Fig. 8B). In contrast to all other correlations, Spearman rank correlation analysis revealed that soil water $\mathrm{NO}_{3}{ }^{-}$was significantly correlated with DCA axis 1 scores of the herbaceous layer on WS4 $\left(r_{\mathrm{S}}=\right.$ $-0.51, P<0.05)$.

Although overstory vegetation patterns do a poor job in explaining spatial patterns of nitrification in WS4, it is not clear what factors cause the low nitrification potentials for plots along the south- to southwest-facing aspect (Fig. 6). To address this, we stratified data for 18 soil and vegetation variables into two groups (the 4 south-facing plots vs. all 11 other plots) and performed $t$ test comparisons between them. In general, $(i)$ soils of the south-facing plots were more acidic and lower in extractable nutrients than soils of the rest of WS4; (ii) nutrient concentrations were lower in herb-layer plants of the south-facing plots; and (iii) trees were smaller on south-facing plots, resulting in lower total basal area (Table 3).

These comparisons suggest that soils of the south- to southwest-facing slope of WS4 are more highly weathered 
Fig. 9. Mean monthly rates of net nitrification (in $\mathrm{g} \mathrm{N} \cdot \mathrm{m}^{-2} \cdot \mathrm{month}^{-1}$ ) from 1993 to 1995 for WS3 (treated), WS4 (untreated), and WS7 (untreated). Values above points are from seven in situ soil incubation plots per watershed.

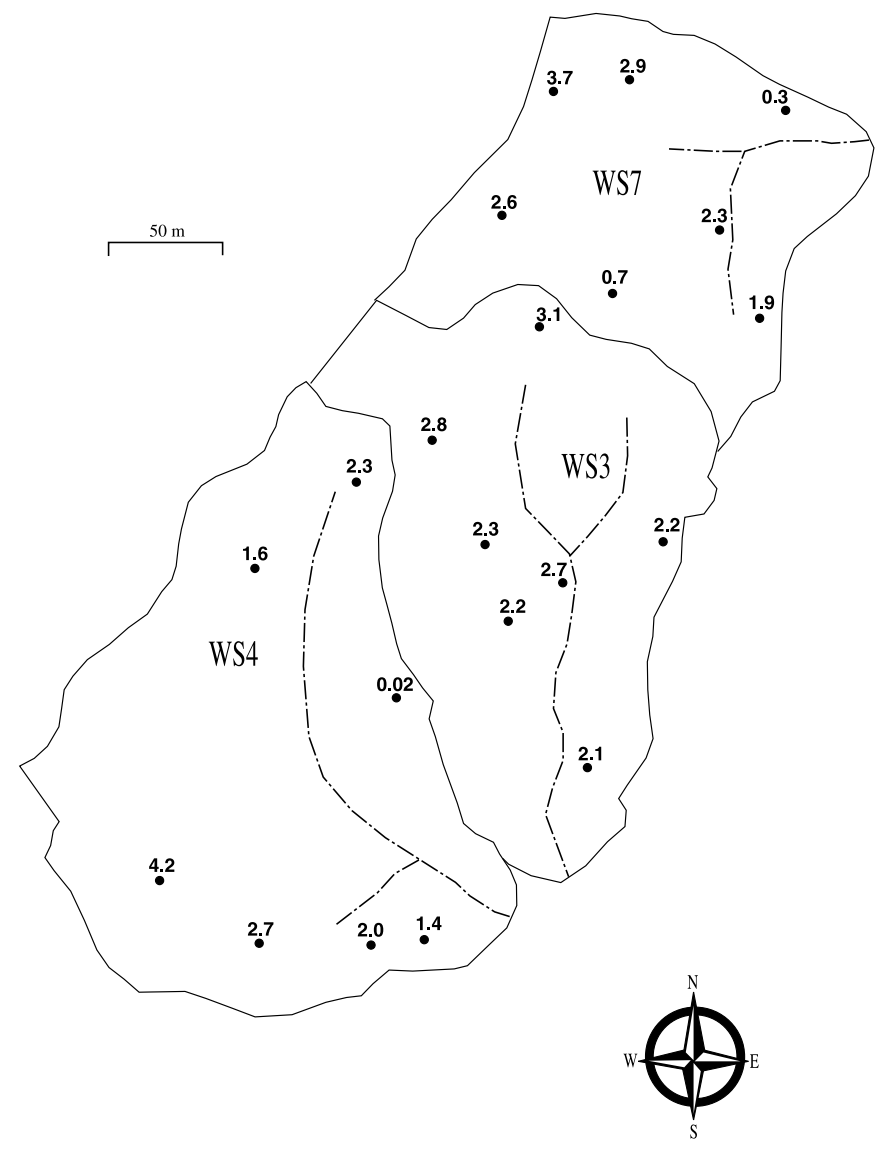

than those of the rest of the watershed, resulting in higher exchangeable acidity and lower exchangeable bases; weathering of silt particles may have resulted in higher clay content in the mineral fraction. Although it is not clear why these soils may have become more highly weathered, differences in microclimate, such as higher incidence of solar radiation (see Tajchman et al. 1997), may have combined with steep slopes to contribute to higher weathering rates.

Lower tissue nutrient concentrations may have arisen from lower nutrient availability (Table 3 ). However, contrasts in herb layer tissue nutrients between the two areas of WS4 are also related to different species in the herb layer along the south- to southwest-facing slopes (Fig. 8B) that prefer more nutrient-poor soils. Herb layer vegetation supported by highly weathered soils has been shown in other studies to be lower in nutrient content than that supported by less weathered soils (Gilliam 1991). As shown in the DCA for the herbaceous layer of WS4 (Fig. 8B), a common species on the weathered slopes of WS4 was Vaccinium vacillans, a member of the Ericaceae. In fact, Vaccinium vacillans was approximately $29 \%$ of herb layer aboveground biomass averaged across the four low soil water $\mathrm{NO}_{3}{ }^{-}$plots along the south- to southwest-facing slopes of WS4, whereas it was not found on any of the other plots (F.S. Gilliam, unpublished data). Such species can maintain, and even increase, soil acidity via preferential uptake of $\mathrm{NH}_{4}{ }^{+}$, rather than $\mathrm{NO}_{3}{ }^{-}$ (Fitter and Hay 1987; Marschner 1995). Furthermore, roots of ericaceous species, such as Vaccinium vacillans, support ericoid mycorrhizae that are capable of secreting organic acids that limit $\mathrm{N}$-mineralizing microbes and, especially, nitrifying bacteria (Straker 1996). Thus, the herbaceous layer, not tree species, may be responsible for limiting $\mathrm{N}$ mineralization and nitrification.

\section{Spatial patterns: net nitrification and correlations with indices of soil $\mathbf{N}$ availability}

Mean monthly net nitrification within sample plots ranged from 2.1 to $3.1 \mathrm{~g} \mathrm{~N} \cdot \mathrm{m}^{-2} \cdot \mathrm{month}^{-1}$ in treated WS3. In untreated WS4 and WS7, these ranges were 0.02-4.2 and 0.3$3.7 \mathrm{~g} \mathrm{~N} \cdot \mathrm{m}^{-2} \cdot$ month $^{-1}$, respectively (Fig. 9). Spatial variability of net nitrification, measured as the coefficient of variation of the mean of all seven plot means shown in Fig. 9, was much greater for the untreated watersheds than for the treated watershed, 63 and 59 versus $15 \%$ (WS4 and WS7 vs. WS3, respectively) (Table 4). Of the other variables compared directly among watersheds, only extractable $\mathrm{NH}_{4}{ }^{+}$ pools had coefficients of variation (CVs) less on WS4 and WS7 than on WS3 (Table 4).

Comparisons across all three watersheds of variability in several indices related to $\mathrm{N}$ dynamics support the conclusion that one of the effects of added $\mathrm{N}$ to forest stands at FEF has been to substantially reduce the natural spatial variability of soil $\mathrm{N}$ transformations. The mean of monthly rates of net nitrification has a coefficient of variation of only $15 \%$ in treated WS3. By contrast, untreated WS4 and WS7 have coefficients of variation of approximately $60 \%$. Thus, net nitrification on the treated WS3 is about four times less spatially variable than on the untreated watersheds.

Results also suggest that $\mathrm{N}$ additions to WS3 may have decreased spatial variability of other measurements of $\mathrm{N}$ in the watershed. For example, extractable $\mathrm{NO}_{3}{ }^{-}$pools were approximately three times more variable in untreated watersheds when compared with WS3 (Table 4). Higher spatial variability of extractable $\mathrm{NH}_{4}^{+}$pools on WS3 may have been related to lack of uniformity in the aerial application of $\left(\mathrm{NH}_{4}\right)_{2} \mathrm{SO}_{4}$. The range of $\mathrm{N} / \mathrm{P}$ ratios of foliage of Viola (16.1-20.8; Table 4) suggests that all three watersheds may be at or above the threshold level of 16, established by Koerselman and Meuleman (1996) to indicate P limitation, rather than $\mathrm{N}$ limitation, of soil for vegetation.

Correlation analyses for all watersheds combined suggest that two factors primarily determined spatial variation in net nitrification at the landscape scale: soil moisture and total soil $\mathrm{N}$, which was related to $\mathrm{N}$ contained in litter (i.e., correlation of total soil $\mathrm{N}$ to litter $\mathrm{N}$ was highly significant, $r=$ $0.72, P<0.01$ ) (Table 5). These analyses also suggest that spatial variation in nitrification rates influenced variation in the size of soil $\mathrm{NO}_{3}^{-}$pools. The significant correlation between nitrification and $\mathrm{N}$ in foliage of Viola rotundifolia is likely the result of $\mathrm{N}$ being taken up by this species as $\mathrm{NO}_{3}{ }^{-}$, also seen in the highly significant $(r=0.86, P<0.01)$ correlation between extractable $\mathrm{NO}_{3}{ }^{-}$and Viola $\mathrm{N}$, and supporting conclusions of Gilliam et al. (1996).

One variable that may have been expected to be a causal factor in patterns of net nitrification was the $\mathrm{C} / \mathrm{N}$ ratio, an indicator of substrate quality for soil microbes. Working across 17 different North American forested sites, van Miegroet et al. (1992) found a negative relationship between 


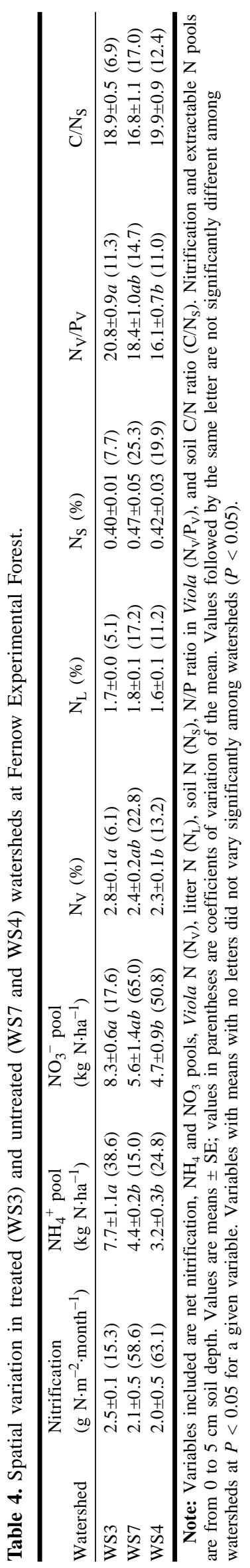

soil $\mathrm{C} / \mathrm{N}$ ratios and $\mathrm{NO}_{3}^{-}$leaching. More recently, Currie (1999) reported a similar negative relationship for five forest sites throughout Europe (part of the NITREX project, see Wright and Rasmussen 1998). In light of these conclusions, the lack of significant correlation at FEF suggests controls on net nitrification by substrate quality (i.e., $\mathrm{C} / \mathrm{N}$ ratios) may operate on spatial scales broader than those represented in this study.

Except soil moisture, all of the variables that were significantly correlated with net nitrification at the landscape scale were also significantly correlated for WS4 alone (Table 5). Thus, conclusions about spatial variability across all watersheds can be made for WS4. That is, spatial variation in soil $\mathrm{N}$, which is determined by litter $\mathrm{N}$, exerts control of variation in net nitrification. Nitrification, in turn, determines the size of soil $\mathrm{NO}_{3}^{-}$pools and availability, as measured by Viola $\mathrm{N}$.

The only significant correlations for net nitrification for WS7 alone were those related to nitrification in soil (i.e., extractable $\mathrm{NO}_{3}{ }^{-}$pools and Viola $\mathrm{N}$ ) (Table 5), not the controls over nitrification, as was seen for WS4 and for all watersheds combined. Thus, although it appears that spatial variation in nitrification determines, in large extent, variation in the size of $\mathrm{NO}_{3}{ }^{-}$pools and availability of $\mathrm{N}$ for plant uptake in WS7, it is less clear what controls spatial patterns of net nitrification in soils of WS7. Two factors (namely size and aspect) are confounded in our design that may explain lack of correlation between net nitrification and potential "control" variables. At 24.2 ha in area, WS7 is $~ 70 \%$ of the area of WS3 (34.3 ha) and $~ 63 \%$ of WS4 (38.7 ha), i.e., we are examining a smaller spatial scale with WS7. In addition, WS7 generally has a north-northeast aspect, in contrast to the south-southeast aspects of WS3 and WS4. Accordingly, other variables not measured in this study, such as soil temperature, may be controlling spatial patterns of nitrification in WS7.

There were no significant correlations of measured variables with net nitrification for WS3 (Table 5). Lack of extensive pretreatment soil and vegetation data preclude a direct assessment of the effects of the $\left(\mathrm{NH}_{4}\right)_{2} \mathrm{SO}_{4}$ additions on spatial variation in $\mathrm{N}$ processing. However, close pretreatment similarities in hydrology and stream chemistry between WS3 and WS4 (Adams et al. 1993), in addition to comparable size and aspect, suggest that pretreatment soil conditions in WS3 may have been similar to those reported here for WS4. Thus, portions of WS3 may have been similar to the southwest-facing areas of WS4 with low nitrification rates and low soil water $\mathrm{NO}_{3}{ }^{-}$. If ericaceous species in the herb layer of WS4 are responsible, in part, for maintaining that part of the watershed in an N-limited state, WS3 may have had that component of the herb layer but lost it as a result of the $\mathrm{N}$ additions. Indeed, Berendse (1998) found that, whereas ericaceous species can inhibit soil $\mathrm{N}$ transformations under ambient conditions, $\mathrm{N}$ additions can eliminate ericaceous species via reduced competitive abilities with other species.

\section{Conclusions: implications for sustainable forest management}

None of the predictions concerning $\mathrm{N}$ saturation articulated by Aber et al. (1989, 1998) addressed the effects of excess $\mathrm{N}$ on either temporal or spatial variability. Peterjohn et 
Table 5. Correlation matrix for several variables related to soil nitrogen dynamics at treated (WS3) and untreated (WS4 and WS7) watersheds of Fernow Experimental Forest.

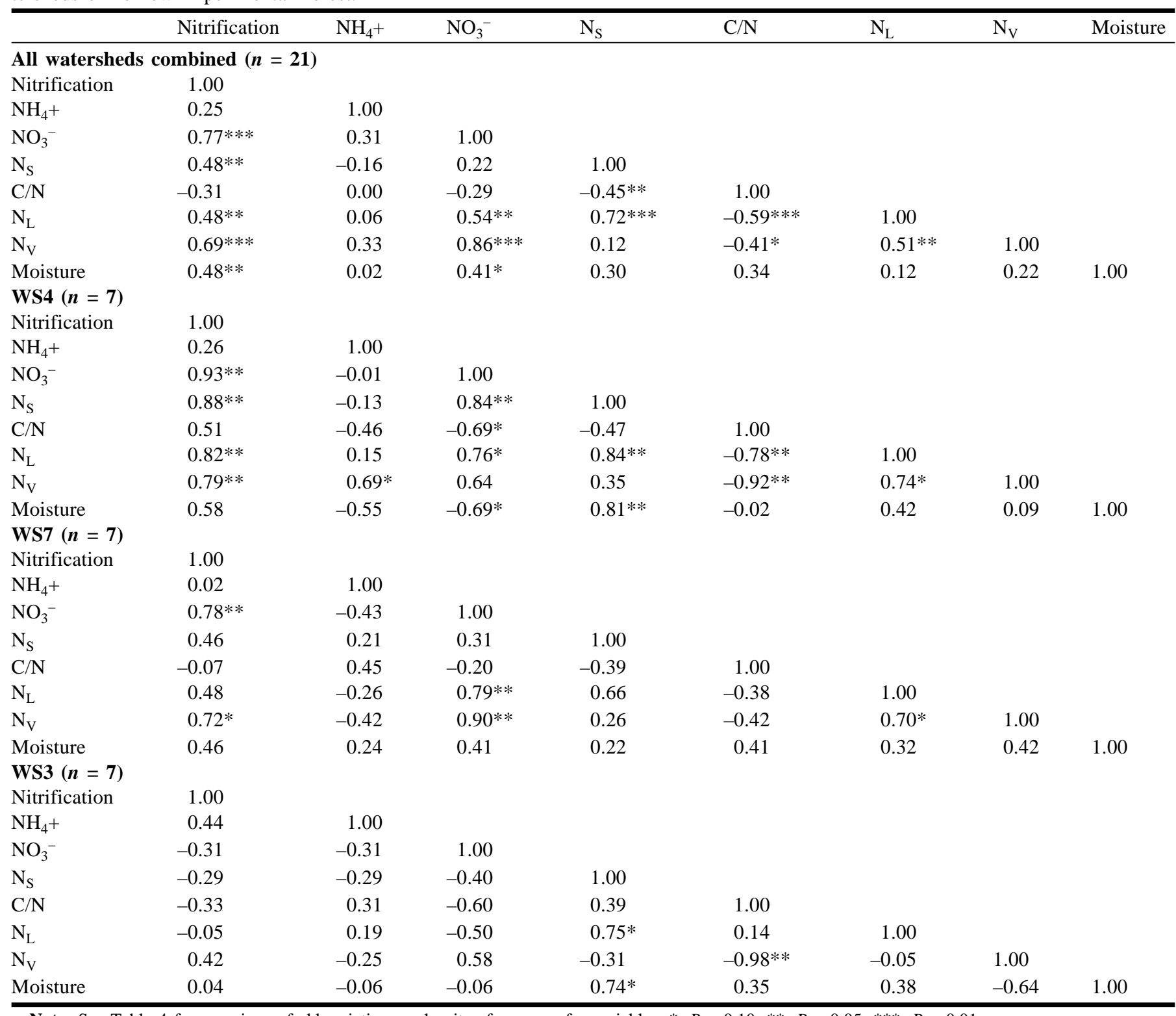

Note: See Table 4 for meanings of abbreviations and units of measure for variables. *, $P<0.10$; **, $P<0.05$; ***, $P<0.01$.

al. (1996) demonstrated that the onset of $\mathrm{N}$ saturation on WS4 over the period 1971-1994 at FEF resulted in lower temporal variability in stream water concentrations of $\mathrm{NO}_{3}^{-}$. Our study suggests that further additions of $\mathrm{N}$ to an $\mathrm{N}-$ saturated system may decrease temporal and spatial variability in $\mathrm{N}$ processing in the soil. Accordingly, an additional predictive hypothesis of $\mathrm{N}$ saturation may be that it results in lower temporal and spatial variability in $\mathrm{N}$ dynamics of forest ecosystems.

Results presented in this paper suggest that excessive $\mathrm{N}$ inputs may have compromised the biotic control of $\mathrm{N}$ cycling in the forests studied at FEF. The ability of an ecosystem to recover from disturbance is determined in large part by biotic control on energy flow and nutrient cycling (Margalef 1968). We believe that these changes in temporal and spatial relationships induced by chronic $\mathrm{N}$ additions indicate that the biotic processes responsible for regulating $\mathrm{N}$ dynamics in forest ecosystems may be altered under conditions of $\mathrm{N}$ saturation. This has important implications for the response of $\mathrm{N}$-saturated forests to disturbances such as wind damage (Everham and Brokaw 1996; Foster et al. 1997; Peterson and Rebertus 1997) or harvesting practices, several of which represent a gradient of disturbance intensity (Gilliam and Roberts 1995). At another N-saturated site in FEF with high preharvest nitrification rates, whole-tree harvesting increased these rates by nearly $150 \%$ in the first year following whole-tree harvesting (Gilliam and Adams 1999). Although Vitousek and Matson (1985) found that harvesting without removing organic debris (which they concluded was the source of microbial immobilization of inorganic N) resulted in negligible loss of $\mathrm{N}_{\text {as }} \mathrm{NO}_{3}{ }^{-}$, harvesting at FEF occurred with minimal disturbance to the forest floor, yet resulted in large increases in $\mathrm{NO}_{3}^{-}$in the mineral soil (Gilliam and Adams 1999). 
Vitousek et al. (1982) concluded that low-N sites would be highly resistant to disturbance, whereas high-N sites would be much less resistant. Spatial analysis of soil water $\mathrm{NO}_{3}{ }^{-}$and net nitrification at FEF indicates that WS4 contained appreciable areas of these extremes of $\mathrm{N}$ availability, with one plot that had the lowest $\left(0.02 \mathrm{~g} \mathrm{~N} \cdot \mathrm{m}^{-2} \cdot \mathrm{month}^{-1}\right)$ and another the highest $\left(4.2 \mathrm{~g} \mathrm{~N} \cdot \mathrm{m}^{-2} \cdot\right.$ month $\left.^{-1}\right)$ values of mean monthly net nitrification of all 21 plots of the 3-year study (Fig. 9). Thus, we would expect a disturbance (e.g., from wind damage) involving only the low N portion of WS4 to bring about few changes as compared with that involving only the high- $\mathrm{N}$ portion. By contrast, because of greater $\mathrm{N}$ availability and mobility and lower spatial heterogeneity due to additions of N, WS3 should display low resistance to such disturbances (sensu Vitousek et al. 1982).

Fenn et al. (1998) discussed several challenges presented by $\mathrm{N}$ saturation for forests of North America, including the sustainable management of $\mathrm{N}$-saturated forests. McLaughlin and Wimmer (1999) further emphasized the seriousness of $\mathrm{N}$ saturation in the context of its effects on $\mathrm{Ca}$ fertility in forest soils. Certainly, this represents a concern for central Appalachian hardwood forests such as FEF (Adams 1999). Although productivity of a large majority of forest ecosystems is limited by $\mathrm{N}$ availability (Vitousek and Howarth 1991), limitation of productivity by base cations has been described also (e.g., Stone and Kszystyniak 1977; Gilliam and Richter 1991). The response of N leaching and base cation mobility to $\mathrm{N}$ inputs at FEF (Adams et al. 1997) suggests that cation availability eventually could limit forest productivity in the region, particularly in conjunction with harvesting (Gilliam and Adams 1999; Adams 1999). Although the rates of $\mathrm{N}$ mineralization reported for FEF are higher than those reported for most sites (Table 1, see also Pérez et al. 1998), they are in agreement with modeled estimates of regional $\mathrm{N}$ mineralization rates by Fan et al. (1998). Thus, conclusions for FEF may be applicable to otherwise similar, but unstudied, hardwood forests of the central Appalachian region of the eastern United States.

\section{Acknowledgments}

Research was funded through NE-4301, Fernow Experimental Forest, Timber and Watershed Laboratory, Parsons, W.V., under USDA Forest Service Cooperative Grants 23$165,23-590$, and 23-842. We acknowledge the excellent field and (or) laboratory assistance of Nicole Welch, Staci Aulick, Anne Hockenberry, and Mark Fisher. Frederica Wood provided invaluable data management. The graphics skills of Beverly Surratt that produced the watershed figures are greatly appreciated. An earlier version of the manuscript was improved by comments from Jeff May, Bill Currie, and two anonymous reviewers.

\section{References}

Aber, J.D., and Melillo, J.M. 1991. Terrestrial ecosystems. Saunders College Publishing, Philadelphia, Pa.

Aber, J.D., Nadelhoffer, K.J., Steudler, P., and Melillo, J.M. 1989. Nitrogen saturation in northern forest ecosystems. BioScience, 39: $378-386$.

Aber, J.D., Magill, A., Boone, R., Melillo, J.M., Steudler, P., and Bowden, R. 1993. Plant and soil responses to chronic nitrogen additions at the Harvard Forest, Massachusetts. Ecol. Appl. 3: 156-166.

Aber, J.D., Magill, A., McNulty, S.G., Boone, R.D., Nadelhoffer, K.J., Downs, M., and Hallett, R. 1995. Forest biogeochemistry and primary production altered by nitrogen saturation. Water Air Soil Pollut. 85: 1665-1670.

Aber, J.D., McDowell, W., Nadelhoffer, K., Magill, A., Berntson, G., Kamakea, M., McNulty, S., Currie, W., Rustad, L., and Fernandez, I. 1998. Nitrogen saturation in temperate forest ecosystems: hypotheses revisited. BioScience, 48: 921-934.

Adams, M.B. 1999. Acidic deposition and sustainable forest management in the central Appalachians, USA. For. Ecol. Manage. 122: $17-28$.

Adams, M.B., Edwards, P.J., Wood, F., and Kochenderfer, J.N. 1993. Artificial watershed acidification on the Fernow Experimental Forest, USA. J. Hydrol. 150: 505-519.

Adams, M.B., Angradi, T.R., and Kochenderfer, J.N. 1997. Stream water and soil solution responses to 5 years of nitrogen and sulfur additions at the Fernow Experimental Forest, West Virginia. For. Ecol. Manage. 95: 79-91.

Analytical Software. 2000. Statistix for Windows, version 7.0 ed. Analytical Software, Tallahassee, Fla.

Barbour, M.G., Burk, J.H., Pitts, W.D., Gilliam, F.S., and Schwartz, M.W. 1999. Terrestrial plant ecology. 3rd ed. The Benjamin/Cummings Publishing Co. Inc., Menlo Park, Calif.

Baron, J.S., Ojima, D.S., Holland, E.A., and Parton, W.J. 1994. Analysis of nitrogen saturation potential in Rocky Mountain tundra and forest: implications for aquatic systems. Biogeochemistry, 27: 61-82.

Berendse, F. 1998. Effects of dominant plant species on soils during succession in nutrient-poor ecosystems. Biogeochemistry, 42: 73-88.

Binkley, D. 1986. Forest nutrition management. John Wiley \& Sons, New York.

Currie, W.S. 1999. The responsive $\mathrm{C}$ and $\mathrm{N}$ biogeochemistry of the temperate forest floor. Trends Ecol. Evol. 14: 316-320.

Currie, W.S., Aber, J.D., and Driscoll, C.T. 1999. Leaching of nutrient cations from the forest floor: effects of nitrogen saturation in two long-term manipulations. Can. J. For. Res. 29: 609-620.

Davidson, E.A., Hart, S.C., and Firestone, M.K. 1992. Internal cycling of nitrate in soils of a mature coniferous forest. Ecology, 73: $1148-1156$.

Devito, K.J., Westbrook, C.J., and Schiff, S.L. 1999. Nitrogen mineralization and nitrification in upland and peatland forest soils in two Canadian Shield catchments. Can. J. For. Res. 29: 1793-1804.

Durka, W., Schulze, E.-D., Gebauer, G., and Voerkelius, S. 1994. Effects of forest decline on uptake and leaching of deposited nitrate determined from ${ }^{15} \mathrm{~N}$ and ${ }^{18} \mathrm{O}$ measurements. Nature (London), 372: 765-767.

Eagar, C., and Adams, M.B. 1992. Ecology and decline of red spruce in the eastern United States. Springer-Verlag, New York.

Emmer, I.M., and Tietema, A. 1990. Temperature-dependent nitrogen transformations in acid oak-beech forest litter in the Netherlands. Plant Soil, 122: 193-196.

Everham, E.M., III, and Brokaw, N.V.L. 1996. Forest damage and recovery from catastrophic wind. Bot. Rev. 62: 113-185.

Fan, W., Randolph, J.C., and Ehman, J.L. 1998. Regional estimation of nitrogen mineralization in forest ecosystems using geographic information systems. Ecol. Appl. 8: 734-747.

Fenn, M.E., and Poth, M.A. 1999. Nitrogen deposition and cycling in Mediterranean forests: the new paradigm of nitrogen excess. In Oxidant air pollution impacts in the montane forests of southern California: a case study of the San Bernardino Mountains. 
Edited by P.R. Miller and J.R. McBride. Springer-Verlag, New York. pp. 288-314.

Fenn, M.E., Poth, M.A., and Johnson, D.W. 1996. Evidence for nitrogen saturation in the San Bernardino Mountains in southern California. For. Ecol. Manage. 82: 211-230.

Fenn, M.E., Poth, M.A., Aber, J.D., Baron, J.S., Bormann, B.T., Johnson, D.W., Lemly, A.D., McNulty, S.G., Ryan, D.F., and Stottlemeyer, R. 1998. Nitrogen excess in North American ecosystems: predisposing factors, ecosystem responses, and management strategies. Ecol. Appl. 8: 706-733.

Ferrari, J.B. 1999. Fine-scale patterns of leaf litterfall and nitrogen cycling in an old-growth forest. Can. J. For. Res. 29: 291-302.

Fitter, A.H., and Hay, R.K.M. 1987. Environmental physiology of plants. 2nd ed. Academic Press, London.

Foster, D.R, Aber, J.D., Melillo, J.M., Bowden, R.D., and Bazzaz, F.A. 1997. Forest response to disturbance and anthropogenic stress. BioScience, 47: 437-445.

Gilliam, F.S. 1991. Ecosystem-level significance of acid forest soils. In Plant-soil interactions at low $\mathrm{pH}$. Edited by R.J. Wright, V.C. Baligar, and R.P. Murrmann. Kluwer Academic Publishers, Dordrecht, the Netherlands. pp. 187-195.

Gilliam, F.S., and Adams, M.B. 1996. Wetfall deposition and precipitation chemistry for a central Appalachian forest. J. Air Waste Manage. Assoc. 46: 978-984.

Gilliam, F.S., and Adams, M.B. 1999. Effects of harvesting on soil nitrogen $(\mathrm{N})$ dynamics in a $\mathrm{N}$-saturated hardwood forest. In Proceedings, 12th Annual Central Hardwoods Conference, 28 Feb. 2 Mar. 1999, Lexington, Ky. Edited by J.W. Stringer and D.L. Loftis. USDA For. Serv. Gen. Tech. Rep. SRS-24. pp. 29-36.

Gilliam, F.S., and Richter, D.D. 1991. Transport of metal cations through a nutrient-poor forest ecosystem. Water Air Soil Pollut. 57-58: 279-287.

Gilliam, F.S., and Roberts, M.R. 1995. Forest management and plant diversity. Ecol. Appl. 5: 911-912.

Gilliam, F.S., Turrill, N.L., Aulick, S.D., Evans, D.K., and Adams, M.B. 1994. Herbaceous layer and soil response to experimental acidification in a central Appalachian hardwood forest. J. Environ. Qual. 23: 835-844.

Gilliam, F.S., Turrill, N.L., and Adams, M.B. 1995. Herbaceouslayer and overstory species in clear-cut and mature central Appalachian hardwood forests. Ecol. Appl. 5: 947-955.

Gilliam, F.S., Adams, M.B., and Yurish, B.M. 1996. Ecosystem nutrient responses to chronic nitrogen inputs at Fernow Experimental Forest, West Virginia. Can. J. For. Res. 26: 196-205.

Gleason, H.A. 1939. The individualistic concept of the plant association. Am. Midl. Nat. 21: 92-110.

Gleason, H.A., and Cronquist, A. 1991. Manual of vascular plants of northeastern United States and adjacent Canada. 2nd ed. New York Botanical Garden, New York.

Goodale, C.L., and Aber, J.D. 2001. The long-term effects of landuse history on nitrogen cycling in northern hardwood forests. Ecol. Appl. 11: 253-267.

Hedin, L.O. 1994. Stable isotopes, unstable forest. Nature (London), 372: 725-726.

Holland, D.M., Principe, P.P., and Sickles, J.E., II. 1999. Trends in atmospheric sulfur and nitrogen species in the eastern United States for 1989-1995. Atmos. Environ. 33: 37-49.

Hurlbert, S.H. 1984. Pseudoreplication and the design of ecological field experiments. Ecol. Monogr. 54: 187-211.

Johnson, D.W. 1992. Nitrogen retention in forest soils. J. Environ. Qual. 21: 1-12.
Johnson, D.W., and Ball, J.T. 1990. Environmental pollution and impacts on soils and forest nutrition in North America. Water Air Soil Pollut. 54: 3-20.

Johnson, D.W., van Miegroet, H., Lindberg, S.E., Harrison, R.B., and Todd, D.E. 1991. Nutrient cycling in red spruce forests of the Great Smoky Mountains. Can. J. For. Res. 21: 769-787.

Kahl, J.S., Norton, S.A., Fernandez, I.J., Nadelhoffer, K.J., Driscoll, C.T., and Aber, J.D. 1993. Experimental inducement of nitrogen saturation at the watershed scale. Environ. Sci. Technol. 27: 565-568.

Kent, M., and Coker, P. 1992. Vegetation description and analysis: a practical approach. CRC Press, Inc., Boca Raton, Fla.

Kim, C., Sharik, T.L., Jurgensen, M.F., Dickson, R.E., and Buckley, D.S. 1996. Effects of nitrogen availability on northern red oak seedling growth in oak and pine stands in northern Lower Michigan. Can. J. For. Res. 26: 1103-1111.

Koerselman, W., and Meuleman, A.F.M. 1996. The vegetation N:P ratio: a new tool to detect the nature of nutrient limitation. $\mathrm{J}$. Appl. Ecol. 33: 1441-1450.

Koopmans, C.J., Lubrecht, W.C., and Tietema, A. 1995. Nitrogen transformations in two nitrogen saturated forest ecosystems subjected to an experimental decrease in nitrogen deposition. Plant Soil, 175: 205-218.

Lawrence, G.B., David, M.B., and Shortle, W.C. 1995. A new mechanism of calcium loss in forest-floor soils. Nature (London), 378: 162-165.

Likens, G.E., Driscoll, C.T., and Buso, D.C. 1996. Long-term effects of acid rain: response and recovery of a forest ecosystem. Science (Washington, D.C.), 272: 244-246.

Lovett, G.M., and Rueth, H. 1999. Soil nitrogen transformations in beech and maple stands along a nitrogen deposition gradient. Ecol. Appl. 9: 1330-1344.

Lovett, G.M., Weathers, K.C., and Sobczak, W.V. 2000. Nitrogen saturation and retention in forested watersheds of the Catskill Mountains, NY. Ecol. Appl. 10: 73-84.

Lynch, J.A., Bowersox, V.C., and Grimm, J.W. 2000. Acid rain reduced in eastern United States. Environ. Sci. Technol. 34: 940-949.

Magill, A.H., Aber, J.D., Hendricks, J.J., Bowden, R.D., Melillo, J.M., and Steudler, P.A. 1997. Biogeochemical response of forest ecosystems to simulated chronic nitrogen deposition. Ecol. Appl. 7: 402-415.

Magill, A.H., Aber, J.D., Berntson, G.M., McDowell, W.H., Nadelhoffer, K.J., Melillo, J.M., and Steudler, P. 2000. Longterm nitrogen additions and nitrogen saturation in two temperate forests. Ecosystems, 3: 238-253.

Margalef, R. 1968. Perspectives in ecological theory. University of Chicago Press, Chicago, Ill.

Marschner, H. 1995. Mineral nutrition of higher plants. 2nd ed. Academic Press, London.

McLaughlin, S., and Percy, K. 1999. Forest health in North America: some perspectives on actual and potential roles of climate and air pollution. Water Air Soil Pollut. 116: 151-197.

McLaughlin, S.B., and Wimmer, R. 1999. Calcium physiology and terrestrial ecosystem processes. New Phytol. 142: 373-417.

McNulty, S.G., and Aber, J.D. 1993. Effects of chronic nitrogen additions on nitrogen cycling in a high-elevation spruce-fir stand. Can. J. For. Res. 23: 1252-1263.

McNulty, S.G., Aber, J.D., and Newman, S.D. 1996. Nitrogen saturation in a high elevation spruce-fir stand. For. Ecol. Manage. 84: $109-121$. 
Mladenoff, D.J. 1987. Dynamics of nitrogen mineralization and nitrification in hemlock and hardwood treefall gaps. Ecology, 68: 1171-1180.

Morris, S.J., and Boerner, R.E.J. 1998. Landscape patterns of nitrogen mineralization and nitrification in southern Ohio hardwood forests. Landsc. Ecol. 13: 215-224.

Morris, S.J., and Boerner, R.E.J. 1999. Spatial distribution of fungal and bacterial biomass in southern Ohio hardwood forest soils: scale dependency and landscape patterns. Soil Biol. Biochem. 31: 887-902.

Niklinska, M., Maryanski, M., and Laskowski, R. 1999. Effect of temperature on humus respiration rate and nitrogen mineralization: implications for global climate change. Biogeochemistry, 44: 239-257.

Norton, S.A., Kahl, J.S., Fernandez, I.J., Rustad, L.E., Scofield, J.P., and Haines, T.A. 1994. Response of the West Bear Brook Watershed, Maine, USA, to the addition of $\left(\mathrm{NH}_{4}\right)_{2} \mathrm{SO}_{4}$ : 3-year results. For. Ecol. Manage. 68: 61-73.

Ohrui, K., and Mitchell, M.J. 1998. Spatial patterns of soil nitrate in Japanese forested watersheds: importance of the near-stream zone as a source of nitrate in stream water. Hydrol. Processes, 12: $1433-1445$.

Ohrui, K., Mitchell, M.J., and Bischoff, J.M. 1999. Effect of landscape position on $\mathrm{N}$ mineralization and nitrification in a forested watershed in the Adirondack Mountains of New York. Can. J. For. Res. 29: 497-508.

Pérez, C.A., Hedin, L.O., and Armesto, J.J. 1998. Nitrogen mineralization in two unpolluted old-growth forests of contrasting biodiversity and dynamics. Ecosystems, 1: 361-373.

Peterjohn, W.T., Adams, M.B., and Gilliam, F.S. 1996. Symptoms of nitrogen saturation in two central Appalachian hardwood forest ecosystems. Biogeochemistry, 35: 507-522.

Peterjohn, W.T., Foster, C.J., Christ, M.J., and Adams, M.B. 1999. Patterns of nitrogen availability within a forested watershed exhibiting symptoms of nitrogen saturation. For. Ecol. Manage. 119: $247-257$.

Peterson, C.J., and Rebertus, A.J. 1997. Tornado damage and initial recovery in three adjacent, lowland temperate forests in Missouri. J. Veg. Sci. 8: 559-564.

Riggan, P.J., Lockwood, R.N., and Lopez, E.N. 1985. Deposition and processing of airborne nitrogen pollutants in Mediterraneantype ecosystems of southern California. Environ. Sci. Technol. 19: 781-789.

Rustad, L.E., Fernandez, I.J., Fuller, R.D., David, M.B., Nodvin, S.C., and Halteman, W.A. 1993. Soil solution response to acidic deposition in a northern hardwood forest. Agric. Ecosyst. Environ. 47: 117-134.

SAS Institute Inc. 1990. SAS/STAT user's guide, version 6. 4th ed. Vol. 2. SAS Institute Inc, Cary, N.C.

Schimel, D., Stillwell, M.A., and Woodmansee, R.G. 1985. Biogeochemistry of $\mathrm{C}, \mathrm{N}$, and $\mathrm{P}$ in a soil catena of the shortgrass steppe. Ecology, 66: 276-282.
Schlesinger, W.H., Raikes, J.A., Hartley, A.E., and Cross, A.F. 1996. On the spatial pattern of soil nutrients in desert ecosystems. Ecology, 77: 364-374.

Stark, J.M. 1996. Modeling the temperature response of nitrification. Biogeochemistry, 35: 433-445.

Stoddard, J.L. 1994. Long-term changes in watershed retention of nitrogen: its causes and aquatic consequences. In Environmental chemistry of lakes and reservoirs. Edited by L.A. Baker. American Chemical Society, Washington, D.C. ACS Adv. Chem. Ser. 237.

Stone, E.L., and Kszystyniak, R. 1977. Conservation of potassium in the Pinus resinosa ecosystem. Science (Washington, D.C.), 198: 192-194.

Straker, C.J. 1996. Ericoid mycorrhiza: ecological and host specificity. Mycorrhiza, 6: 215-225.

Tajchman, S.J., Fu, H., and Kochenderfer, J.N. 1997. Water and energy balance of a forested Appalachian watershed. Agric. For. Meteorol. 84: 61-68.

ter Braak, C.J.F. 1990. Update notes: CANOCO version 3.10. Agricultural Mathematics Group, Wageningen, the Netherlands.

Tietema, A., and Verstraten, J.M. 1991. Nitrogen cycling in an acid forest ecosystem in the Netherlands under increased atmospheric nitrogen input: the nitrogen budget and the effect of nitrogen transformations on the proton budget. Biogeochemistry, 15: $21-46$.

van Miegroet, H., Cole, D.W., and Foster, N.W. 1992. Nitrogen distribution and cycling. In Atmospheric deposition and forest nutrient cycling. Edited by D.W. Johnson and S.E. Lindberg. Springer-Verlag, New York. pp. 178-196.

Vitousek, P.M., and Howarth, R.W. 1991. Nitrogen limitation on land and in the sea: how can it occur? Biogeochemistry, 13: 87115.

Vitousek, P.M., and Matson, P.A. 1985. Disturbance, nitrogen availability, and nitrogen losses in an intensively managed loblolly pine plantation. Ecology, 66: 1360-1376.

Vitousek, P.M., Gosz, J.R., Grier, C.C., Melillo, J.M., and Reiners, W.A. 1982. A comparative analysis of nitrification and nitrate mobility in forest ecosystems. Ecol. Monogr. 52: 155-177.

Walley, F.L., van Kessel, C., and Pennock, D.J. 1996. Landscapescale variability of $\mathrm{N}$ mineralization in forest soils. Soil Biol. Biochem. 28: 383-391.

Williams, M.W., Baron, J.S., Caine, N., Sommerfeld, R., and Sanford, R., Jr. 1996. Nitrogen saturation in the Rocky Mountains. Environ. Sci. Technol. 30: 640-646.

Wright, R.F., and Rasmussen, L. 1998. Introduction to the NITREX and EXMAN projects. For. Ecol. Manage. 101: 1-7.

Yin, X. 1992. Empirical relationships between temperature and nitrogen availability across North American forests. Can. J. For. Res. 22: 707-712.

Zar, J.H. 1996. Biostatistical analysis. 3rd ed. Prentice-Hall, Englewood Cliffs, N.J. 